\title{
Patolojik Narsisizm: Duygusal İstismar ve "Gaslighting" Perspektifinden Kapsamlı Bir Değerlendirme
}

\author{
Aslı Dila AKİ̧̧ ${ }^{1} \quad$ Erdinç ÖZTÜRK ${ }^{2}$
}

Atıf/C: Akiş, A. D. \& Öztürk, E. (2021). Patolojik Narsisizm: Duygusal İstismar ve "Gaslighting" Perspektifinden Kapsamlı Bir Değerlendirme. Artuklu Insan ve Toplum Bilim Dergisi, 6 (2), 131.

$\ddot{O} \mathbf{z}$

Kendini aşırı önemseme, abartılmış benmerkezcilik ve kişilerarası ilişskilerde problemler ile karakterize olan patolojik narsisizm gösteren bireyler, duygusal ilişkilerinde arzularını ve megaloman duygularını tatmin etme amaçlı diğer kişilere karşı hem empati eksikliği göstermekte hem de onları duygusal açıdan istismar etmeye eğilimli olabilmektedir. Gaslighting, narsisistik bireyin partneri üzerinde güç ve kontrol kurmaya çalıştığı duygusal ilişki içerisinde gelişebilen hem onun şahsi yargı, düşünce ve deneyimlerine olan inancını hem de kendisine olan güven duygusunu zedeleyebilen benliğe yönelik bir duygusal istismar biçimi olarak tanımlanmaktadır. Duygusal istismar ise, kişilik gelişimini negatif yönde etkileyen ve psikiyatrik bozuklukların etiyolojisinde temel bir öneme sahip başlica faktörlerden biridir. Olumsuz bir yaşam deneyimi olarak değerlendirilebilen patolojik uzun dönemli duygusal ilişsi esnasında veya sonrasında mağdur; travmatik bağlanma ve reviktimizasyon ile karakterize olan dissosiyatif bozukluk ve/veya travma sonrası stres bozukluğu tanısı alabilmektedir. Psikoterapi adına duygusal istismarın narsisistik bireylerin kurduğu romantik ilişkilerde ortaya çıkış ritüellerine ve partnerleri üzerindeki negatif yönelimli psikolojik etkilerine açıklık kazandırmak temel bir gerekliliktir. Duygusal istismara dair yapılan çalışmalar, hem toplumda patolojik düzeydeki narsisistik bireylerin fark edilebilmesine hem de narsisistik istismarı önleme çalışmalarının ivme kazanmasına önemli katkılar sağlamaya devam etmektedir. Bu çalışmada patolojik duygusal ilişki içerisinde yer alan narsisistik bireylerin partnerleri üzerinde kullandığı duygusal istismar ve gaslightingin ortaya çıkış biçimleri ve mağdurun ruhsal yapısı üzerindeki negatif etkileri kapsamlı bir şekilde değerlendirilecektir.

Anahtar Kelimeler: Narsisizm; duygusal istismar; gaslighting; yakın partner ilişkileri; ihanet travması; travmatik bağlanma.

\footnotetext{
${ }^{1}$ Uzm. Klinik Psikolog, Asli Dila Akiş, İstanbul Üniversitesi-Cerrahpaşa, asliakis@ gmail.com, 0000-0002-2827-8106

${ }^{2}$ Prof. Dr. Erdinç Öztürk, İstanbul Üniversitesi-Cerrahpaşa, erdincerdinc@ hotmail.com, 0000-0003-1553- 2619

Geliş/Received: 22 Ekim 2021, Kabul/Accepted: 25 Kasım 2021
} 


\title{
Pathological Narcissism: A Comprehensive Evaluation from the Perspective of Emotional Abuse and "Gaslighting"
}

\author{
Aslı Dila AKİŞ Erdinç ÖZTÜRK
}

Citation/C): Akiş, A. D. \& Öztürk, E. (2021). Pathological Narcissism: A Comprehensive Evaluation from the Perspective of Emotional Abuse and "Gaslighting". Artuklu Human and Social Science Journal, 6 (2), 1-31.

\begin{abstract}
It is known that individuals who show pathological narcissism, which is associated with excessive self-care, exaggerated egocentrism, and problems in interpersonal relationships, have a lack of empathy to others, and are prone to emotional abuse, which paves the way for using others to satisfy their megalomaniac desires and feelings of self-satisfaction in their emotional relationships. Gaslighting is defined as a form of emotional abuse towards the self, which can develop in an emotional relationship where the narcissistic individual tries to establish power and control over his partner and can damage both his partner's belief in his own judgment, thoughts, and experiences and his sense of self-confidence. Emotional abuse, on the other hand, is one of the main factors that negatively affect personality development and have etiological importance in the foundation of psychiatric disorders. The victim during or after the pathological long-term emotional relationship, which can be considered as a negative life experience; can be diagnosed with dissociative disorders and/or post-traumatic stress disorder that are characterized by traumatic attachment and revictimization. It is very valuable for the process of psychotherapy to clarify the rituals of emotional abuse that occurs in close emotional relationships involving narcissistic individuals, and the negative psychological effects on the partners who are emotionally involved with narcissistic individuals. Studies on emotional abuse continue to make significant contributions to both the recognition of pathological narcissistic individuals in society and the acceleration of efforts to prevent narcissistic abuse. The aim of this study is to comprehensively evaluate the emergence of emotional abuse and gaslighting used by narcissistic individuals in pathological emotional relationships on their partners and their negative effects on the psychological structure of the victim.
\end{abstract}

Keywords: Narcissism; emotional abuse; gaslighting; intimate partner relationships; betrayal trauma; traumatic attachment. 


\section{GíRIŞ}

Psikoterapilerde kendini aşırı önemseme, başkalarını yok sayma, abartılmış benmerkezcilik ve kişilerarası ilişkilerde problemler ile karakterize patolojik narsisistik özellikler gösteren bireylerin danışanla olan iletişim dinamikleri açısından duygusal ilişki süreçleri değerlendirilirken öncelikle bu bireylerin duygusal istismar yöntemlerini ve narsisistik istismar ile yakın ilişki gösteren 'gaslighting' kavramlarını fark ettirmek ve tanımlamak temel bir gerekliliktir (Thomaes, Bushman, De Castro \& Stegge, 2009: 1238). Duygusal istismar stratejilerine yönelik yapılan bilimsel çalışmalar, patolojik düzeydeki narsisistik bireyleri fark etme ve onların narsisistik istismarlarını önlemeye yönelik uygulanabilir strateji ve tekniklere önemli katkılarda bulunmaktadır. Patolojik/maladaptif narsisizm ile erken yaşta başlayan kronik çocukluk çağı travmaları arasında yakın bir ilişki bulunmaktadır. "Patolojik narsisizm" ve "gaslighting" kavramlarıly fonksiyon geçişleri bulunan dissosiyatif bozukluklar ve travma sonrası stres bozukluğu; yineleyici erken yaşta başlayan çocukluk çağı travmaları; öfke patlamaları, işitsel ve görsel halüsinasyonlar, cinsel fonksiyon bozuklukları, kendine zarar verme davranışları, kimlik karmaşaları, amneziler, konsantrasyon bozuklukları ve intihar girişimleri ile karakterizedir (Öztürk, 2021: 145).

Patolojik narsisizm gösteren bireylerin özellikle erken çocukluktan ergenlik dönemine olan uzamda majör oranda güvenli bağlanma sürecini yaşayamadıkları bilinmektedir. Özellikle erken çocukluk dönemi, her birey adına psikolojik, sosyal ve kişilik özelliklerinin gelişiminde kritik bir öneme sahiptir. Bu doğrultuda patolojik narsisizmin gelişiminde, çocukların ebeveynleri tarafından gelişimsel ihtiyaçlarının yeterince karşılanmaması ve şiddet odaklı empatiden uzak yanlış çocuk yetiştirme stillerinin uygulanması öncül bir öneme sahiptir (Erikson, 1968; Karpel, 1976: 70). Patolojik düzeyde narsisistik özellikler gösteren bireylerin duygusal ilişkilerinde istismar dinamikli tutum ve davranışlar göstermeye belirli oranda yatkın oldukları ifade edilmektedir. Narsisist bireyler büyük oranda partnerine karşı suçlayıcı tutum ve davranışlarda bulunmakta, egonsantrik ihtiyaçlarını onu kontrol ederek ve duygusal açıdan istismar ederek tatmin etmekte ve ilişkiye dair sorunların partnerinden kaynaklı olduğunu sıklıkla ve şiddetle vurgulayarak kimlik ve benliğe yönelik bir istismar biçimi olarak tanımlanan "gaslighting" yöntemini uygulamaktadır. Günümüz postmodern toplumunda küçümsenemeyecek oranda duygusal ilişkilerde yaşantılanan bu istismarın: "gaslighting", mağdurlar üzerinde yarattığı psikopatolojilerin farkedilmesi, tan1 ve tedavi sürecine katk1 sağlamak adına oldukça önemlidir (Howard, 2019: 645; Campbell \& Foster, 2002: 341).

\section{Narsisizm Kavramının Operasyonel Tanımı ve Narsisistik Kişilik Bozukluğu}

Yunan mitolojisindeki Narcissus efsanesinden ismini alan, insanın kendi fiziksel görünümüne duyduğu sevgi olarak ifade edilen ve bir tür kişilik yapılanması olarak da bilinen "narsisizm", geçmişten günümüze olan uzamda psikolojinin odak konuları arasinda yer almaktadır (Twenge ve ark., 2008: 877; Wardetzki, 1991: 11). Narsisizm kelimesi ilk olarak 1898 yılında psikanalitik kuramcı Ellis tarafından kişinin kendine ve vücuduna yönelttiği beğeni, cinsel arzu ve haz olarak tanımlanmıştır. Bu tanıma göre narsisizm, özellikle kadınlarda görülen ve bireyin cinsel dürtülerini kendisine hayranlık 
duyarak yöneltmesini içeren duygulardır (Özsaydın, 1984; Rozenblatt, 2002: 37). Narsisizm kavramı, Freud'un "Narsisizm Üzerine Bir Giriş” adlı makalesinden sonra sıkça araştırılmaya başlanmıştır. Narsisizm üzerine çalışan en önemli teorisyenler; nesne ilişkileri kuramcılarından Otto Kernberg (1975) ve kendilik psikolojisi kuramcılarından Heinz Kohut (1977)'tur. Kernberg ve Kohut narsisizmin soğuk, ilgisiz ve çocuğun ihtiyaçlarını karşılamak için yetersiz olan ebeveynlikten kaynaklandığını vurgulamaktadır. Theodore Millon (1981) ise narsisizmin aşırı hoşgörülü ve çocuklarına hayran olan ebeveynler tarafından geliştirildiğini savunmuştur. Bu bağlamda Öztürk şımartılmanın bir disfonksiyonel iletişim dinamiği olarak patolojik narsisizmin oluşumunda etken bir ajan olduğunu öne sürmektedir. Çocukların psikososyal gelişimini tehdit edebilen patolojik narsisizm, klinik psikoloji, psikiyatri, psikotarih, adli psikoloji ve psikotravmatoloji başta olmak üzere birçok disiplinin ve alanın temel çalışma konusunu oluşturmaktadır (Otway \& Vignoles, 2006: 110; Öztürk, 2020: 379; Trumpeter, Watson, O’Leary \& Weathington, 2008: 59).

Narsisizm, sıklıkla kendini beğenmişlik, başkalarına karşı kendini kanıtlama ihtiyacı ve abartılmış benmerkezcilik özellikleriyle karakterizedir. Narsisist bireylerin özsevgi ve benlik algılarının bozulmuş olduğu ve genelde grandiyöz görünümünün arkasında; savunmasız, umutsuz, kabul görmeye ve kendi kimliğinin yansımasına aç bir çocuk saklandığı önemle vurgulanmaktadır (Wardetszki, 1991: 18). Literatürde narsisizm, kendiliği aşırı önemseme, başkalarını yok sayma ve kişilerarası ilişkilerde problemler ile ilişkilendirilmektedir (Kealy \& Rasmussen, 2012: 358). Bireyin başarısızlık ve yenilgiler karşısında ruhsal gücünü toparlayabilmesi için bireysel amaçlarına yönelik olarak narsisizmin kullanılması ve koruyucu bir faktör olarak ifade edilmesi "normal narsisizm" çerçevesinde ele alınmaktadır (Pincus \& Lukowitsky, 2010: 436). Ayrıca, narsisistik özellikler gösteren bireylerin sayısının "kuşaktan kuşağa" arttığı iddia edilmektedir. Brown (2017), 1980 ile 2004 yılları arasında doğmuş olan çocukların büyükanne ve büyükbabalarına kıyasla daha fazla narsisistik özelliklere sahip olduğunu belirtmiştir. Öte yandan, gelişen teknoloji ile üretim odaklı, bireyselliğin önem kazandığı modern yaşam; dayanışma ve dostluk duygularından çok saldırganlık, egemenlik, rekabet ve çatışma ilişkisini beslemekte ve "her bir bireyi diğerinin karşısına koyan" bir düzeni temsil etmektedir (Talu, 2010: 151). Modern yaşamın bireyselleşmeye yönelik taleplerini karşılamak adına empati kurmadan ilerlemeye çalışan bireyler, narsisistik bir patern geliştirmeye oldukça yatkındır. (White, Szabo \& Tiliopoulos, 2018: 72). Benmerkezci olan bireyler, nesnelere ve başka insanlara ilişkin gerçekleri fark etmede ve diğer bireylerin bakış açılarını, neler düşündüklerini ve hissettiklerini kavramada büyük oranda başarısız olmaktadır (Dökmen, 1977). Narsisistik özellikleri olan bireylerin başkalarıyla iletişim kurarken dikkatini karşısındakine vermemesi ve onlara empatik bir şekilde yaklaşmaması, benmerkezciliğin temel karakteristikleridir (Spencer, 2001). Dolayısıyla, içinde bulunduğumuz yüzyılda benmerkezciliğin "narsisizm çă̆l" olarak adlandırılması ile narsistisik davranışlar belirli oranda yaşantılanmaya devam etmektedir (Twenge, Konrath, Foster, Campbell, \& Bushman, 2008: 920).

Kişinin kendisine dair olumlu duygu ve düşüncelerinin olması ve başkalarından hak ettiğini düşündüğü değeri görme beklentisi normal narsisizm olarak değerlendirilmektedir. Bu beklentilerin karşılanmadığı durumlarda öfke, hayalkırıklığı ve 
üzgünlük gibi olumsuz duyguların ortaya çıkması 'narsisistik yaralanma' olarak tanımlanmakta ve bu süreç olağan bir dinamik olarak -psikopatolojik bir karakteristikten ziyade- yaşantılanmaktadır. Dolayısıyla, narsisistik yaralanmalar hayatımızın bir parçası olmak ile birlikte her bireyin özdeğer duygusunu da belirli oranda sarsabilmektedir. Narsisistik yaralanmaların özdeğer duygusunu sarsma şiddeti, narsisizmin psikiyatrik bir bozukluk olarak değerlendirilmesini de etkileyebilmektedir. Özgüveni ve kendine verdiği değeri optimal olan bireyler, reddedilme veya negatif eleştiri karşısında üzgünlük, hayal kırıklığı ya da kızgınlık gibi duyguları belirli seviyede yaşantılarken kendine verdikleri değeri ve sevgiyi büyük oranda kaybetmezler. Fakat patolojik boyutta narsisistik özellik gösteren bireyler reddedilme ve eleştiriyi güvensizlikle karşılayarak, özdeğerinin zarar görmemesi adına savunmaya geçebilir ve kişilerarası ilişkilerinde saldırgan bir tutum sergileyebilir. Sonuç olarak, bireyin tehdit karşısında uygun/sağlıklı baş etme mekanizmaların kullanamaması ile karakterize olan patolojik narsisizm kavramı ortaya çıkmıştır (Pincus \& Lukowitsky, 2010: 35).

İlk kez DSM-III (1980)'de tanımlanan patolojik narsisizm kavramı, DSM-IV ile birlikte eksen II bozukluklarında "narsisistik kişilik bozukluğu" tanı kategorisi kapsamında değerlendirilmiştir (APA, 1987; 1994; 2000). Son olarak, DSM-5'de özsever (narsisistik) kişilik bozukluğu, erken erişkinlikte başlayan ve değişik bağlamlarda ortaya çıkan, büyüklenme (düşlemlerde ya da davranışlarda), beğenilme gereksinimi ve eşduyum yapamama ile giden ve aşağıdaki kriterlerden en az beşini kapsayan bir örüntü olarak tanımlanmıştır (APA, 2013: 333):

1. Büyüklenir (örn. başarılarını ve yeteneklerini abartır; gösterdiği başarılarla orantısız bir biçimde, üstün biri olarak görülme beklentisi içindedir).

2. Sınırsız başarı, güç, zekâ, güzellik ya da yüce bir sevgi düşlemleriyle uğraşır durur.

3. Özel” ve eşi, benzeri bulunmaz biri olduğuna ve ancak özel ya da üstün diğer kişilerce (ya da kurumlarca) anlaşabileceğine ve ancak onlarla ilişki kurması gerektiğine inanır.

4. Çok beğenilmek ister.

5. Hak ettiği duygusu içindedir (özellikle kayırılacak bir tedavi göreceğine ya da her ne istiyorsa yapılacağına ilişkin anlamsız beklentiler içinde olma)

6. Kendi çıkarı için başkalarını kullanır (kendi amaçlarına ulaşmak için başkalarından yararlanır).

7. Eşduyum yapamaz: başkalarının duygularını ve gereksinimlerini anlamak istemez.

8. Sıklıkla başkalarını kıskanır ya da başkalarının kendisini kıskandığına inanır.

9. Başkalarına saygısız davranır, kendini beğenmiş davranışlar ya da tutumlar sergiler (DSM-5; American Psychiatric Association, 2013: 333). 


\section{Adaptif: "Normal Narsisizm" ve Maladaptif: "Patolojik Narsizm"}

Narsisizm, geçmişten günümüze doğru uzanan alanyazında birçok farklı psikopatolojik karakteristiğiyle multidisipliner bir çalışma konusu olarak hem akademik hem de klinik açıdan yoğun bir ilgi görmüştür hatta görmeye de devam etmektedir. Narsisizmi, Ackerman ve arkadaşları (2011: 71) uyumlu (adaptif) ve uyumsuz (maladaptif) narsisizm olarak iki boyutta ele almaktadır. Narsisistik yaralanmalar karşısında özdeğer duygusunu koruyabilme kapasitesi olarak tanımlanan "adaptif narsisizm", optimal düzeydeki ruh sağlı̆̆ ve psikolojik dayanıklılık ile yakından ilişkilidir. (Sedikes, Campbell, Reeder, Elliot \& Gregg, 2004: 115). "Maladaptif narsisizm” ise; negatif yönelimli benmerkezci özellikler ve patolojik kontrol etme isteği ile karakterize olup bu kapsamda değerlendirilen bireyler başkalarının ilgisine/onayına sürekli ihtiyaç duymaktadır (Pincus \& Lukowitsky, 2009: 432). Adaptif narsisizm, normal/sağl1klı bir süreç iken maladaptif narsisizm ise patolojik bir süreç olarak fonksiyon görmektedir (Brown, 1998; Pincus \& Lukowitsky, 2010: 425). Adaptif: normal/sağlıklı narsisizm, gelişmiş sosyal beceriler ve olumlu benlik imajını içermekte iken patolojik narsisizm ise; (1) nüfuzunu orantısız bir şekilde kullanarak başkalarını kontrol etme ihtiyacı ve (2) empati eksikliği açısından normal/sağliklı narsisizmden farklılık göstermektedir (Miller \& Campbell, 2008: 460). Genel olarak patolojik narsisizm, öz düzenleme becerilerinde yaşanan eksiklikler ya da güçlükler ile yakından ilişki göstermektedir (Ackerman ve ark., 2011: 63).

Patolojik veya maladaptif narsizm, büyüklenmeci ve kırılgan narsisizm olarak ikiye ayrilmaktadır (Ackerman ve ark., 2011: 65; Miller, Gentile, Wilson \& Campbell, 2013: 285; Wink, 1991: 591). Kurılgan narsisistlerin normalden sapma gösteren büyüklenmeciliği içeren grandiyöz fantezileri olmasına rağmen bu kişiler çekingen ve güvensiz oldukları için görünürde "narsisist" olarak algılanmazlar. Büyüklenmeci narsisistler daha yüksek düzeyde mutluluk ve yaşam doyumuna sahip olup -asıl/gerçek mutluluk ve yaşam doyumu değil- (Rose, 2001: 381) kırılgan narsisistlere kıyasla daha teşhircidir (Wink, 1991: 593). Bu iki boyutta yer alan bireylerin ortak noktaları, başkalarına karşı düşmanca ve saldırgan davranma eğiliminde olmalarıdır (Miller, Gentile, Wilson \& Campbell, 2013: 286). Kibirlilik, teşhircilik, küstahlık, kıskançlık ve haset duyguları, aşırı talepkarlık, düşük kaygı düzeyi, dikkat çekme çabası ve diğerlerinin ihtiyaçlarını yoksayma gibi özellikler ile karakterize olan büyüklenmeci narsistler kişilerarası ilişkilerde sömürücü ve kıskanç tutumlar sergilemekle birlikte sosyal çevrelerinde cesur ve çekici olarak kendilerini gösterebilmektedirler (Akhtar \& Thomson, 1982: 15; Wink, 1991: 592). Başkalarının değerlendirmelerine karşı aşırı duyarlı, baskılandığı ve acı çektiği düşünceleri ile meşgul bir yapıya sahip, sosyal alanlarda güvensiz ve mütevazı bir görünüm sergileyen ve kaygı düzeyi yüksek olan kırılgan narsisistler ise kişilerarası ilişkilerinde büyüklenmeci taleplerini gizlerken aynı zamanda başkaları üzerindeki ruhsal etkilerinin ve duygusal yetersizliklerinin de belirli ölçülerde farkındadırlar (Gabbard, 1989: 529; Akhtar, 1989: 509). Kırılgan narsisistler yüksek ahlaki değerlere sahip görünen bu çekingen tavırlarına rağmen büyüklenmeci narisistlerle aşırı kendine odaklanma, kendilerinden ve çevrelerinden gerçek dışı yüksek beklentiler içerisinde olma, altta yatan kırılgan benlik duygusu, yetersizlik duygusuna savunmacı bir yaklaşım, sınırsız güç ve ün fantezileri gibi özellikler ile benzer bir çekirdek yapıya sahiptirler (Akhtar, 2003; Dickinson \& Pincus, 
2003: 201; Masterson, 1993). Bu durumu "narsisizmin iki yüzü" olarak tanımlayan Wink (1991: 595), büyüklenmeci narsisistlerin başkalarını yetenek ve başarılarıyla etkilemeye çalışırken diğerlerinin tepkilerini filtreleme yoluyla narsisistik yaralanmalardan kendilerini izole ettiklerini, kırılgan narsisistlerin ise özgüvenlerini korumak adına kendilerini savunmasız hissettikleri durumlarda kaçınma davranışı göstererek diğerlerinin davranışlarını anlamak adına yoğun bir uğraş sergilediği üzerinde durmuştur (Gabbard, 1989: 529; 1998: 132). Sosyal alanlarda ve kişilerarası ilişkilerde iki uç görünümlerde olabilen fakat patolojik narsisizm kavramı altında yer alan kırılgan ve büyüklenmeci narsisizmin ayrımının yapılması bu iki alt tip grubun uyum ve psikopatoloji göstergeleriyle farklılık göstermesinden ötürü duygusal ilişkilerinde de farklı davranış kalıpları gösterebildiği için önem taşımaktadır (Pincus \& Roche, 2011: 34).

Büyüklenmeci ve kırılgan görünümlerde olan patolojik narsisistlerin en temel özelliği, öz saygılarını güçlendirmek için başkalarından sürekli ilgi ve yakınlık talep etmeleridir (Morf \& Rhodewalt, 2001: 180). Onların diğer bir temel özelliği ise, arzularını ve kendini beğenme duygularını tatmin etmek ve gerçekleştirmek için ilişkilerini ve başkalarını orantısız bir şekilde manipüle etmelerine neden olan empati kesintileridir (Ritter ve ark., 2011: 244). Büyüklenmecilik duygusu (kişinin kendi yetenekleri abartması ve mükemmelliğine dair gerçekçi olmayan algıları), narsisistik (özsever) kişilik bozukluğu ile diğer kişilik bozuklukları arasındaki ayırt edici bir özellik olarak işlev görmektedir (Ronningstam \& Gunderson, 1991: 228). Narsisistik bireyler büyük oranda, kendilerini fazlasıyla olumlu değerlendirme, çıkarlarına ulaşmak için başkalarını manipüle etme ve karşısındakilerin duygu ve endişelerini göz ardı etme eğilimindedir (Barry, Frick ve Killian, 2003: 141; Sedikides, Campbell, Reeder, Elliot ve Gregg, 2002: 110). Bu eğilim, özellikle partneri tarafindan şiddet ve olumsuz geri bildirimlerle karşılaşıldığında artmaktadır (Bushman \& Baumeister, 1998: 221; Ronningstam \& Gunderson, 1991: 227). Ayrıca narsisistik bireyler tehdit altında hissettikleri ilişkilerin içerisindeyken, şişirilmiş benlik imajını korumak adına büyük bir çaba sarf etmektedir (Campbell, Reeder, Sedikides \& Elliot, 2000: 336). Kernberg (1975) ve Kohut (1977) narsisizmin; büyüklenmecilik, bencillik, teşhircilik, kibir, kırılgan benlik saygısı ve duygusal istikrarsızlık gibi özelliklerle karakterize olduklarını belirtmektedir. Bu özellikler, narsisist bireylerin davranışlarında ve düşüncelerinde tutarsızlıklara ve git-gellere sebep olabilmektedir (Kernberg, 1975, 2010: 260; Miller, Widiger \& Campbell, 2010: 643).

\section{Patolojik Narsisizm, Çocuk Yetiştirme Stilleri ve Bağlanma}

Ebeveyn ile çocuk arasındaki ilişkinin niteliği, çocuğun kişiliğinin pozitif yönde sürdürülmesinde temel bir belirleyici olarak işlev görmektedir. Bu ilişki aracılığıyla çocuk; benlik, bireysellik ve benzersizlik duygusu kazanır. Ebeveyn ile olan ayrılma-bireyleşme, erken çocukluk ve ergenlikte sıkça görülen gelişimsel zorluklara neden olmaktadır. Ebeveynden ayrılma-bireyleşme sürecini yeteri düzeyde tamamlamayan çocukların özbakım becerilerini yetişkin desteği olmadan gerçekleştirememe, sosyal ilişki kurmada zorluk yaşama, yetersiz sosyal beceriye sahip olma, özgüven eksikliği, düşünce, duygu ve davranışlarının sorumluluğunu alamama, isteklerini ve düşüncelerini doğrudan ifade edememe, benlik saygısının düşük olması, öğrenmeye dair içsel motivasyonun az olması, 


\section{Duygusal İstismar ve "Gaslighting" Perspektifinden Kapsaml Bir Değerlendirme}

onay beklentisinin fazla olması, kendi eylemlerini başlatamama ve düzenleyememe gibi benlik ve kimlik gelişimini yavaşlatan ve dolayısıyla yetişkinlik sürecinde gelişebilecek psikopatolojilerine zemin hazırlayan özellikleri olabilmektedir (Türktan \& Savran, 2010: 246). Çocukluk çağı dönemi -özellikle $0-6$ yaş aralığı-, bireylerin psikolojik, sosyal ve kişilik özelliklerinin temellerinin atıldığı en majör dönemdir. Margaret Mahler "İnsan Yavrusunun Psikolojik Doğumu" kitabında çocuğun yaşamının başlangıcındaki - ilk 36 ayanne-baba ile okul öncesi çocuk arasındaki ilişki gelişimini ve ebeveyn ile çocuk arasındaki ilişkiyi ayrıntılı bir psikanalitik bakış açısından tanımlarken, bebeklerin ilkel düzeyde de olsa kendi kimliklerini oluşturmaya yönelik temelleri atmaya başladıkları 'psikolojik doğum' kavramına vurgu yapar. Mahler'e göre, biyolojik doğum ve psikolojik doğum birbirinden farklı nitelikleri barındıran ve eşzamanlı olmayan kavramlardır. Biyolojik doğum daha gözlemlenebilir ve sınırları belirgin iken, psikolojik doğum ise yavaş gelişen ve kişiliğin oluşumunu belirleyen en temel süreçlerden biridir (Mahler, Pine \& Bergman, 1975). Dolayısıyla, kişilik özelliklerinin oluşumunda, ebeveyn-çocuk ilişkisinin psikolojik doğuma olan etkisinin önemi kaçınılmazdır.

Biyopsikososyal açıdan gelişim sürecinde bulunan çocuk, bebeklikten yetişkinlik dönemine kadar olan uzamda insanların diğer bireylere olan tutum ve davranışları ile kendi ruhsal stabilitesini ve tepkilerini nasıl kontrol edebileceğini öğrenmektedir. Tüm bunları öğrenmek, kişinin birincil bakımverenleri ile yakın bir etkileşim ve güvenli bağlanma ilişkisini gerektirir (Bowlby, 1973). Destekleyici ve empati yönelimli çocuk yetiştirme stilleri, kişinin öz değerine pozitif yönde katkı sağlayarak sağlam bir özgüven gelişimi için temel oluşturur. Ebeveynlerin çocuk yetiştirme stilleri "şiddet odakl1", "yetersiz" ve "empati açısından eksik" olduğunda çocukta, olumsuz bir benlik gelişebilmekte ve başkalarıyla etkileşimde bu benliğin etkileri sıç̧a ortaya çıkarak istikrarsız ve vulnerabl ilişki dinamikleri yaşantılanabilmektedir. Fiziksel ve duygusal açıdan yetersiz, empatiden uzak ve şiddet odaklı çocuk yetiştirme stillerini uygulayan ebeveynler, çocukları tarafından "kötü nesneler" olarak algılanmalarına rağmen özellikle 0-3 yaş dönemindeki çocuklar için çaresizce ihtiyaç duyduğu güvenliği ararken özdeşleşeceği tek kişi yine bu "kötü nesne" olan kendileridir (Lapsley \& Stey, 2010: 4; Öztürk, 2020: 353). Dolayısıyla çocuk tarafından içselleştirilen "kötü nesneler" yine çocuğun kendine yönelik olumsuz benlik algısı geliştirmesine ve yetişkinlik sürecinde yaşayacağı duygusal ilişkilerde partnerini "kötü" bir birey olarak algılamasına zemin hazırlayabilmektedir. Çocukluk döneminde başlayan ve yetişkinlikte devam eden ebeveynden ayrılma, bireyleşme ve kimlik inşası, narsisizmin gelişiminde önemli bir konuma sahiptir. (Karpel, 1976: 70). Erikson (1968) psikososyal gelişim basamaklarında ifade ettiği üzere yeterli düzeyde otonomi ve öz yeterlilik kazanılmamasının, çocuklarda utanç ve şüphe duygularının ortaya çıkmasına ve bu duygular ile başa çıma sürecine karşlık geliştirilen şişirilmiş benlik algısına sebep olabileceğini önemle vurgulamaktadır. Narsisizmin, çocukluk döneminde bakımverenler tarafından gelişimsel ihtiyaçların yeterince karşılanmaması, ebeveynden erken ya da travmatik bir biçimde ayrılma ve optimal düzeydeki bireyleşmenin ruhsal açıdan sağlıklı gerçekleşmediği "tekamüle ulaşmamış otonomi” ile ilişkili olabileceği belirtilmektedir (Erikson, 1968; Öztürk, 2020: 354).

Rappoport'a (2005: 3) göre narsisistik ebeveynler, çocukları ile güvenli bağlanma kurma sürecini başarılı bir şekilde sürdümekte zorlanmaktadır. Bu süreçte ebeveynler, 
ortaya çıkan sorunlardan ötürü büyük bir oranda denetimlerini sağladıkları çocuklarını "suçlayarak" kendi "mükemmel ebeveynlikleri"nin sorgulanmasına izin vermezler. $\mathrm{Bu}$ ebeveynler, başkalarının görüşlerine tahammül edemezler ve çocuklarının sevgi, ilgi ve şefkat gibi duygusal ihtiyaçlarından habersizdirler. Narsisistik ebeveynler görmek istedikleri şekilde çocuklarını yetiştirirken, onların da kendilerini pozitif bir imaj çerçevesinde algılamalarını isterler. Ayrıca bu narsisistik ebeveynler, çocuklarından göstermek istedikleri imajı oluşturmada destek sağlayacak davranışlar talep ederler. Çünkü onları hem kendi sürekliliği ya da uzantısı olarak hem de duygusal ihtiyaçlarını karşılamanın bir yolu/aracı olarak algılarlar (Rappoport, 2005: 4).

Kernberg (1975) narsisizmin temelinde soğuk ve ilgisiz olmakla karakterize reddedici ebeveynlik stillerinin yattığına vurgu yaparken, Kohut (1977) ise bu reddedici ebeveynlik stili ile birlikte aynı zamanda çocuğu aşırı şımartan ebeveynlik stilinin de var olduğunu belirterek aşırı idealize edilen ebeveynin negatif ruhsal etkisi üzerinde durmaktadır. Bu iki uçta tanımlanan ebeveynlik stillerinin narsisistik örüntü gelişiminde etkili olduğuna dair destekleyici araştırmalar bulunmaktadır (Millon, 1981; Otway \& Wignoles, 2006: 107; Eldoğan, 2016: 4). Ayrıca, duygusal ve fiziksel açıdan ihmal edilen çocukların zaman içerisinde geliştirdikleri korkulu bağlanma stilinin narsisistik örüntünün bir parçası olan kişilerarası ilişkilerde problem yaşama ve yakınlaşamama ile ilişkili olduğu da belirtilmiştir (Dickinson \& Pincus, 2003: 191).

Öztürk'e (2021: 3) göre çocukta oluşan psikopatoloji ile ailenin bütününde varolan psikopatoloji benzer karakteristiktedir. Bu psikopatolojinin oluşumunda erken yaşta başlayan kronik çocukluk çağı travmaları ile empatiden ve karşılıklılıktan uzak şiddet odaklı yanlış yetiştirme stilleri birincil öneme sahiptir. Ebeveynler arasındaki tutarsızlık, istismarı inkar eden ya da normalleştiren tutum, empati eksikliği, aile üyeleri arasındaki "mesafe-ayar" sorunları, öfke patlamaları, kendine zarar verme davranışları, alkol madde bağımlılığı, güvensiz bağlanma, anne-babanın çocuk algısındaki negativiteler, duygusal ilişkilerde manipülasyon, haset ve kıskançlık yanlış çocuk yetiştirme stillerine sahip ailelerin temel özellikleri olarak fonksiyon görmektedir (Öztürk, 2021: 4). Psikotarihe göre ise, çocukluk çağı travmalarının temelinde, yetişkinlerin ruhlarında katlanamadıkları parçaları başka bir beden üzerinde ve özellikle de çocukları üzerinde kontrol ederek kendilerine yönelik olan tehditi, şiddet odaklı yanlış çocuk yetiştirme stilleri aracıllı̆ı ile onlara yansıtma arzuları bulunmaktadır (deMause, 1997: 11; Öztürk, 2021: 5).

\section{Duygusal İlişkilerde Narsisistik İstismar}

Ebeveynlerin çocuklarına uyguladığ 1 "duygusal istismar" teriminden esinlenerek üretilen "narsisistik istismar", yetişkin bireylerin ikili ilişkilerindeki disfonksiyoneliteyi tanımlamak için kullanılmaktadır (Ferenczi, 1984: 293; Miller, 1995). Duygusal yakınlık gerektiren; partner, aile, arkadaşlık ve iş ilişkilerinde ortaya çıkabilen narsisistik istismar, patolojik düzeyde narsisistik özelliklere sahip olan bireylerin manipülatif yollarla başkalarına zarar vermesi olarak tanımlanır (Bonchay, 2018). Bu konuda bilimsel farkındalığın artması ve psikolojik anlamda olumsuz sonuçlara sebep olmasını önleme amaçlı duygusal ilişkilerde narsisistik istismarı fark etmek ve hangi dinamiklerle ilişkili olduğunu belirlemek son derece önemli bir husustur. 


\section{Duygusal İstismar ve "Gaslighting" Perspektifinden Kapsaml Bir Değerlendirme}

Narsisistik birey, partnerini duygusal açıdan kendisini tamamlaması/karşılaması doğrultusunda manipülatif bir yönelimle "kullandığı" için bu kişinin ilişkideki mevcudiyeti ve rolleri oldukça önemlidir. Bireylerin duygusal ilişkilerinin başlangıcı; idealleştirme evresi, ortasi; değersizleştirme evresi ve sonuncusu; mevcut partneri terk etme evresi olarak görülen belirli davranışlarla karakterize bir narsisistik istismar modeli bulunmaktadır. Tipik olarak, duygusal ilişkinin başlangıcında narsisist birey, kısa zaman uzamlarında şefkat ve ilgi seline boğabileceği empatik doğaya sahip bir partner seçer. Narsisistin partnerine yoğun ilgi göstererek, onun özelliklerini yücelttiği bu ilişkinin başlangıç aşaması 'idealleştirme evresi' olarak tanımlanmaktadır. Bu yüceltme davranışı partneri üzerinde derin ve pozitif bir etki bırakır. Bu kişi, yeni partnerinin (narsisist) sahte bir temsilini gördüğü için onunla "görünürde" güçlü bağlar kurmaktadır. Bu sahte temsil, narsisistin hem yeni partneri tarafindan nasıl görünmek istediğinin bilinçli bir inşası sonucunda hem de çocukluk çağı travmaları ile ivme kazanarak gelişen narsisistik kişilik örüntüsü ile fonksiyon geçişleri olan yarı bilinçli/bilinçdışı süreçler tarafından ortaya çıkabilmektedir (Howard, 2019: 648).

Narsisist birey sıklıkla, kendisine yarar sağlayan özelliklere sahip olan ya da hayranlık yoluyla özgüvenini artıracak bir partner seçer. Bu seçim doğrultusunda, yeni partnerini kendi benliğini yüceltmeye araç olabilecek özel niteliklere sahip bir "ödül” olarak görebilir. Seçilen partner zaman içerisinde narsisistik bireyin idealize edilmiş sahte imajına inanarak, kendisinin önemli bir yere sahip olduğunu düşündüğü "duygusal ilişki"sine bağlanır. Narsisist birey, partnerinin ona bağlandığını farkettiği noktada ilişkisindeki bağlılığı kötüye kullanma aşamasına geçer ve bu süreç 'değersizleştirme evresi' olarak tanımlanır (Howard, 2019: 650). Bu aşamada, narsisistin gerçek benliği ortaya çıkar ve partnerinin benlik duygusunu yok etmeye yönelik aşağılayan bir tutum sergileyerek onu değersizleştirmeye başlar. Aşağılayan tutum aynı zamanda davranışları görmezden gelmeyi ve partneri ile ilgili toplum içerisinde disfonksiyonel yorumlar yapmayı da içerebilir (toplum içerisindeki bireyler yorumların mağdur için yıpratıcı olduğunu farketmeyebilir) (Howard, 2019: 651). Narsisistler, aşağılayıcı yorumlarının ve davranışlarının partnerlerinin benlik duygusuna zarar vereceğinin tamamen farkındadır. Vaknin (2003), narsisistik yapıdaki bireylerin hatalı eylemlerinde kendilerini sorumlu tutmadıkları ve bu eylemlerinin zarar verici sonuçlarını tahmin etmelerine rağmen umursamadıklarını belirtmektedir (Arabi, 2017).

Narsisistler, ilişkilerinin başlangıcında kendi duygusal ihtiyaçlarını karşılayan partnerlerine değer verdiklerini gösteren tutum ve davranışları iradi olarak kurgulamaktadır. Ancak duygusal ilişki içerisinde narsisistler, partnerleri tarafından tehdit edildiklerini ve aşağılandıklarını hissederek kendilerine yöneltilen sistematik istismarı fark edebilirler (Arabi, 2017). Bu olumsuz duygular ile başa çıkmakta güçlük çeken narsisist, partnerini değersizleştirerek şişirilmiş sahte benliğini koruyacaktır. Değersizleştirmeden sonraki son aşama olan "mevcut partneri terk etme" aşamasında narsisist, genellikle yeni bir partner arayışına başlarken aynı zamanda halihazırdaki birlikteliğine devam ettiği karmaşık ve etik olmayan ilişki(ler) yaşantılayabilmektedir. Bu aşamada narsisist, partnerinin kendi gerçekliği hakkında yargılarını sorgulamasına ve benliği ile ilgili şüpheye düşmesine neden olan ince ipuçları ve şifreli konuşmalar yapmayı içeren "gaslighting" gibi istismar teknikleri kullanabilmektedir. Duygusal istismar uygulayan kişinin başka bir ilişki 
yaşadığına dair açık bir kanıt ortaya çıkmasına rağmen bu istismarcı bireyler, ilişkileri olduğunu inkâr ederek yalan söyleyebilir, partnerlerini kandırabilir ya da onları fazla/abartılı düzeyde şüpheci olmak ile suçlayabilir. $\mathrm{Bu}$ durum, partneri tarafından manipüle edilen bireyin kafasını karıştırarak hem kendisinden şüphe duymasına hem de fikir ve eylemlerini gereksiz bir şekilde sorgulamasına neden olabilmektedir (Howard, 2019: 649).

Narsisist birey, genellikle partnerine karşı suçlayıcı tutum ve davranışlarda bulunarak ihanet davranışları da dâhil olmak üzere gelişen herhangi bir ilişki sorununun ondan kaynaklı olduğunu sıklıkla ve şiddetle vurgulayarak "gaslighting" uygular. Her şeyin sorumlusu olarak gördüğü ve iradi bir şekilde manipüle ettiği partneri ile kurduğu ilişkiye dair sorumluluk ve karar almaktan itina ederek istismar ettiği kişiyi yalnız bırakır. Duygusal istismar mağduru birey, narsisist partnerinin gerçek davranışını ortaya çıkararak onu bu durumla yüzleştirirse psikolojik açıdan yıldırma, zarar verme veya benliğini yok etmeye yönelik hâlihazırda belirli ölçüde kendisine uygulanan "gaslighting" ya da "duygusal istismar" stratejilerinin şiddetinin artırılmasına sebep olabilir. Narsisistin, partneri hakkında gerçek olmayan söylentiler yaymak da dâhil olmak üzere, öfkesini şiddetli bir biçimde dışavurması ise muhtemeldir. Ayrıca narsisist birey, partneri hakkında gerçek olmayan ya da çarpıtılmış söylemleri onun arkadaşlarına ve ailesine inandırıcı görünmesi adına uydurabilir. $\mathrm{Bu}$ durum, narsisistin intikam arayışındaki öfkesinin, saldırganlığının ve yıkıcılığının bir tezahürü olarak ortaya çıkmaktadır (Kohut, 1972: 375). Narsisist, duygusal ilişki içerisindeyken kendisini kurban olarak sunarak partnerinde suçluluk duygusu yaratıp onun üzerinde güç ve kontrol sağlayabilmektedir.

Partneri üzerinde kontrolü ve gücü sürdürebilmek adına kullanılan duygusal istismar tekniklerinden bir başkası ise 'sessiz muamele'dir. Bu teknik, sessizliğin hesaplaşma stratejisi olarak kullanıldığı, bireyin karşısındakine tepkisiz kalarak gösterdiği pasif doğalı manipülatif bir reaksiyondur. Kişi karşısındakini görmezden gelerek, konuşmayarak ve sessiz kalarak ilişkiye veya partnerine dair hoşnutsuzluğunu ifade eder. Bu teknik, iş arkadaşılılarının yanısıra evlilik ya da dostluk gibi kişilerarası ilişkilerde de kullanılmaktadır (Bies, 2009: 161). Sessiz muameleye maruz kalan mağdur, neden bu şekilde kendisine davranıldığına ilişkin birçok sorusunun yanıtsız kalması sebebiyle yalnız hissedebilir. Narsisist birey yeni bir partner ile "duygusal istismar" yönelimli bir ilişkiye başladığı zaman manipülasyon ve gaslighting gibi birçok baskı ve itaat ettirme modelini onu kontrol etmek için kullanabilmektedir. Yeni partnerine kendisini, duygusal açıdan stabil olmayan ve istismar odaklı bir ilişki içerisindeki "masum kurban" konumundaymış gibi gösterebilir. Narsisistik birey, yeni partneri ile kurduğu duygusal ilişkinin ilk aşamasında genellikle daha önceki ilişkisinde yaşantıladığı sürecin aynısını tekrarlayacaktır (Howard, 2019: 652). Duygusal istismarı içeren iletişim stratejilerini kullanarak ve ilişkinin başında önceki partnerine yaptığı şekilde yeni partnerini yoğun ilgi gösterek ve sahte kimliği ile manipüle ederek, kontrol ve istismarı uygulayabileceği bir zemin oluşturabilmektedir. Mağdur, narsisist partnerinin yeni duygusal ilişkisine tanık olma durumunda derin bir ihanet duygusu yaşayabilir ve kendisini geçmiş ilişki deneyimlerinin gerçek olmadığına inanan "tek kullanımlık bir nesne" gibi hissedebilir. Mağdurun yaşantıladığı "ihanet duygusu" ve "nesne gibi hissetme" durumu, ayrıldı̆̆ narsisist partneri ile yaşantıladığ 1 deneyimin benzerinin bir başkası ile tekrarlanması ile 
ilişkilidir. Narsisist birey, terk ettiği partnerini "duygusal açıdan instabil olan istismarc1 kişis" olarak kategorize ederek onunla hesaplaşma sürecine girebilir. Bu hesaplaşmayı, hem terk ettiği partneri hem de yeni partneri ile aynı anda birlikteyken yapabilmektedir. Narsisist bireyin ilişkiye dair kontrolünü sürdürebilmesi için üçüncü bir kişiyi -özellikle çatışma ve tartışmaların yoğun olduğu dönemlerde- bu kaotik dinamiğe dahil etmesine 'üçgenleştirme' denir. Terk edilen kişi, duygusal istismarı yalnızca narsisist partneri tarafindan değil, aynı zamanda bu narsisist bireyin yeni partneri tarafindan da belirli oranlarda yaşantılayabilir (Howard, 2019: 653).

Duygusal istismar, aile içi şiddeti açıklamaya yönelik teorik ve kuramsal yaklaşımlarda da sıkça yer almaktadır. Duygusal istismar bağlamında değerlendirilebilen narsisistik istismarın temel bileşenlerinin incelenmesi, bu kavramı tanımlamak ve çalışmak adına destekleyici bir rol üstlenmektedir. Duygusal istismarda bulunan bireylerin davranışlarının altındaki itici güçler ile onların psikopatolojik yapıları arasındaki ilişkiyi aydınlatmak son derece önemlidir. Narsisistik yapıdaki bir istismarcının y1kıcı davranışlarının arkasındaki temel itici güçler olan "sınırsız yetki sahibi olma inancı" ve "üstün öz imajına odaklanma", bireyin inşa ettiği kişiliğinin ayrılmaz parçalarıdır. Narsisistik bireyin odak noktası ve endişesi, davranışlarının bir ötekini nasıl etkileyebileceğinden ziyade ihtiyaçlarının karşılanması üzerine yoğunlaşmaktadır (Campbell \& Foster, 2002: 490).

Narsisist partner ile olan ilişki sürecinde gizli veya sinsice gerçekleşmiş olan istismar, duygusal birliktelik tehdit altındayken veya sona erdirildiğinde, farklı boyutlarda da ortaya çıkabilir. Tehdit ve terk etmeye yönelik tetiklenme halinde istismarcı, kurbanın benlik duygusunu ve ilişkinin geçmişinde meydana gelen olayların gerçekliğini zedelemek/yıkmak için kullandığı 'gaslighting' gibi duygusal istismar stratejilerini daha şiddetli uygulayabilir ya da yeni bir istismar stratejisi geliştirme yoluna girebilir. Bu süreç, genellikle bir sonraki hedefe/kurbana geçmeyi mümkün kılmaktadır. Çoğu zaman, bir kurban yalnızca ilişkinin sonunda istismara uğradığını fark edebilir, çünkü kullanılan stratejiler gizlice gerçekleşmiştir ve yalnızca ilişkinin ayrılık sürecinde şiddetli ve görünür hale gelmiştir. Duygusal ilişkinin sonlandırılması sürecinde narsisist birey, partnerinin kendi "ihtiyaçlarını doyurmadığı" ya da "narsisistik arzularını" karşılamadığı sonucuna varabilir. Narsisistik arzu, narsisistin öz saygısını beslemek için ihtiyaç duyduğu duygusal uyarılma olarak tanımlanmaktadır. Narsisistik bireyi harekete geçiren, kararlarının ve davranışlarının temelinde yatan başkalarının onay ve beğenisini almaya yönelik olan patojen bağlanma karakteristikleridir (Vaknin, 2019). İstismarc1, partneriyle ilişkisini sonlandırmayı düşündüğü andan itibaren onun üzerinde hiçbir kontrolü olmadığını düşünmeye başlayabilir. Bu nedenle istismarcı, değersizleştiren, aşağılayan ve rencide edici tavırlarıyla psikolojik itibarsızlaştırma tekniklerini kullanarak partnerine zarar verebileceği ve ardından da onu terk edilebileceği aşamaya gelebilir. "İlişki şantajı”" olarak adlandırılan durumda narsisist bireyin partnerini "sürüncemede olan" ilişkisine geri çekmeye çalışması, daha fazla ilgi almak, narsisistik aruzularını doyurmak, kendi benlik saygısı ve ilişki üzerindeki yetkisine dair inancını güçlendirebilmek amacıyla gerçekleştirilmektedir (Howard, 2019: 650). 


\section{Kimliğe ve Benliğe Yönelik Bir İstismar Türü: Gaslighting}

Gaslighting, hem disfonksiyonel ailelerde dominant olan ebeveynin diğer aile üyesini kontrol ve itaat ettirme odaklı primitif davranışlarını içermekte hem de bu istismarı uygulayan kişiye kuvvetle bağımlı hale getirmeye zemin hazırlamaktadır. Gaslighting, patolojik doğalı duygusal ilişkilerde partnerler arasında ve iş yerinde patron-çalışan etkileşimlerinde ortaya çıkabilmektedir. Manipülasyona maruz kalan birey kendi iradesi ve bilgisinden bağımsız, isteğinin dışında etkilenme ve yönlendirmeye açık olurken, bağımlı hale gelmeye, kendi çelişkileri içerisinde çaresizlik duygusunu deneyimlemeye, değersizlik ve suçluluk hissetmeye, tehdite ve yalana da maruz kalmaya yatkın durumdadır. Bu durum altında kişide davranış değişiklikleri ve algı çarpıtmaları ortaya çıkabilmektedir. Alg1 çarpıtmalarının yoğun ortaya çıktığı gaslighting, temelini ilkel sosyal sistemler içerisinde uyumsuz olarak kodlanan kadın düşmanlığından almaktadır. Zaman içerisinde aile, iş ve sosyal hayatın içerisinde de ortaya çıkan gaslighting patolojik bir iletişim biçimidir. Gaslighting, duygusal ilişkilerde daha sıklıkla erkek tarafından kadına uygulanan bir istismar yöntemi olmasına rağmen dominant doğalı kadınların resesif yapıdaki erkek partnerlerine yönelik de ortaya çıkabilmektedir. Flört ve evlilik ilişkilerinin yanısıra aile sistemi içerisinde çocuklar da gaslighting mağduru olabilmektedirler (Öztürk, 2021: 18).

İstismara yönelik artan bilimsel farkındalık düzeyi ile birlikte önplana çıkan 'gaslighting', kimlik ve benliğe yönelik bir istismar biçimi olarak tanımlanmaktadır. "Suçlu bir adamın eşinin mental fonksiyonlarının bozulduğuna/kesintiye uğradığına dair onu manipüle etmeye çalışması" konulu 1938'deki Gas Light adlı bir oyundan türetilen "gaslight" terimi, 1940 ve 1944 yıllarında da birçok filmde odak konu olarak işlenmiştir. Bu oyun ve film başlıkları, erkek kahramanın eşine, kendi akıl -ruh- sağlığından şüphe duymasına sebep olacak stratejilerden biri olarak evlerinde gaz 1şıklarının söndügünü hayal ettiğini dayattığı olay örgüsünden türetilmiştir. Hikâyede erkek kahraman, eşini mali kazanç için kasitlı olarak manipüle eder. Oyun ve film kurgusunda, gaslighting terimi yalnızca bir ötekinin akıl sağlığından şüphe duymasına neden olmak anlamında kullanılırken, günümüzde buna ek olarak güç ve kontrolle ilgili olan fenomenler ile de ilişkilendirilmektedir (Spear, 2020: 230). Gaslighting, hem son onlu y1llarda duygusal ilişkilerdeki istismar türü hem de siyasi liderlerin kullandığı bir yöntem (Stern, 2007; Carpenter, 2018) olarak fonksiyon görmektedir. Bilimsel platformlarda "gaslighting" ilk olarak psikanalitik yönelimli araştırmalarda (Calef \& Winshel, 1981: 45) kullanılmışken, yakın geçmişte ise özellikle felsefe kapsamında yoğun bir şekilde çalışılmaktadır (Abramson, 2014: 5).

Gaslighting uygulayan kişi -istismarcı veya gaslighter-, duygusal istismar yöntemleriyle karşısındaki kişinin zamanla kendisinden şüphe duymasına yol açar. Gaslighting mağduru, kurban veya gaslightee, maruz kaldığı duygusal istismar için kendisinin birincil sorumlu olduğunu düşünmektedir ya da bu şekilde düşünmeye zorlanmaktadır. Gaslighting mağduru en sonunda kendilik algısını, kimlik duygusunu ve öz saygısını yitirme noktasına gelebilir. Gaslighting, kurbanın kendine olan güveninin istismarcı tarafından zayıflatılma girişimini içerir. Kendisini bağımsız bir yargı odağı olarak gören gaslighter, kurbanını süreğen bir eleştiriye maruz bırakarak kendi bakış açısına rıza göstermesini sağlamaya çalışır ve böylece kurban üzerindeki kontrolünü sağlar ve sürdürür. Gaslighter, yoğun ve sistematik eleştirilerini partner ya da otorite konumundan 


\section{Duygusal İstismar ve "Gaslighting" Perspektifinden Kapsamlı Bir Değerlendirme}

yararlanarak, mağdurun kendisine olan güvenini bir manipülasyon, uydurma ve aldatma stratejisi şeklinde kullanmaktadır (Spear, 2020: 232). Öztürk (2021: 18) özellikle aşağılık ve yetersizlik duyguları ile başa çıkma becerisinden yoksun narsisistik ve megalomanik yapıdaki erkeklerin kadın partnerlerini bu yöntemler aracıllı̆ıyla travmatize ve dissosiye ederek kontrol etme arzularını beslediği üzerinde durmaktadır. Gaslighting süreçlerinde "Bu senin iyiliğin için.", "Bak bana yine ne yaptırdın ki zaten bu senin suçun”, "Sen böyle davranmasaydın bütün bu gerginlik hiç olmayacaktı.", "Aslında gerçekte birbirimizden çok da farkl düşünmüyoruz ama şu anda benim istediğim gibi davranmak hem senin ve benim hem de geleceğimiz adına önemli pozitif bir ilk adım olacak." ya da "Gitmek senin bir seçimin ancak eğer gidersen her ikimize de ne olacă̆ını bilemem. "gibi bask1 odaklı ve itaat ettirici kontrol kurmaya yönelik cümleler kullanılmaktadır (Stark, 2019: 224; Yalçın \& Öztürk, 2018: 46).

Gaslightingin ayırt edici özelliği, gaslighterin sadece kurbanını kontrol etmesinin ya da ilişkisinin kendi istediği şekilde gitmesine dair yaptığı yönlendirmesinin yanı sıra onun kendisiyle aynı fikirde olmasını da manipülatif stratejilerle sağlamasıdır (Abramson, 2014: 12). Bunu sağlamak için öncelikle mağdurun "susturulması" ve diğer herkesin onun yanlış olduğuna inandığı bir ortamın oluşturulması gerekmektedir. Mağdur bu durumu başlangıçta onaylamasa veya fark etmese dahi nihayetinde kabul etmekten başka bir seçeneği olmadığı düşüncesine kapılması sistematik bir şekilde gerçekleştirilen istismarın temel bir özelliğidir. Gaslighter, duygusal açıdan istismar ettiği ilişkisinden, güç ve kontrolü elinde tutma motivasyonuyla beslenmektedir (Wagers, 2015: 234). Diğer istismar yöntemleri gibi, gaslighting de mağdurlar üzerinde dissosiyatif bozukluklar ve travma sonrası stres bozukluğu gibi uzun dönemli negatif ruhsal etkiler yaratmaktadır. Ayrıca istismarcıların duyguları kavrama ve ifade etme sürecinde yaşadıkları zorluklar, değişken frustrasyon toleransları ve öz değerleri, patolojik düzeyde narsisist olan bireylerin özellikleri ile benzerlik göstermektedir (Smith, 2007: 196; Wagers, 2015: 235).

Abramson (2014: 10) gaslighting'i, bu eylemi yapan kişinin diğer bireylerin tepkilerinin, algılarının ve/veya inançlarının hatalı olduğunu onlara empoze etmesinin yanı sıra "delilik" şeklinde nitelendirilebilecek kadar oryantasyonu olmayan davranış ve düşünceleri teşvik etmeye çalıştı̆̆ duygusal bir manipülasyon biçimi olarak tanımlamaktadır. Gaslighting, kişinin kendi yargılarına, düşünce ve deneyimlerine olan inancını ve bunlar üzerindeki kontrolüne dair güven duygusunu kesintiye uğratmaktadır (Welch, 2008). Bu patolojik istismar, hem kişinin ruh sağlı̆̆ını olumsuz yönde etkilemekte hem de maruz kaldığı negatif olayların tek sorumlusu olarak kendisini görmesine sebep olabilmektedir (Simon, 2010). Abramson (2014: 14) ayrıca gaslighter'ın karşısındakinin davranışlarından bir şekilde yararlanabileceğini, ancak bunu yapmak için birden fazla motivasyona sahip olabileceğini belirtmektedir. Daha da önemlisi, gaslighter büyük oranda iradi şekilde hareket etmesine rağmen, bazen davranışlarının altında yatan motivasyonun farkında olmayabilmektedir. Gaslighting'in zaman içinde birden fazla olayı içermesi ve birden fazla kişi tarafindan yapılması oldukça muhtemeldir (Abramson, 2014: 15). Gaslighting, daha belirgin güç eşitsizliklerinin olduğu durumlarda gerçekleşebilir veya bu durumların daha şiddetli etkileri de olabilir. (Abramson, 2014: 15). Örneğin bu dinamiklere, ebeveynlerin çocukları ya da partnerleriyle olan ilişkilerinde sıkça rastlanmaktadır. Gaslighting, narsisistik bireyin partneri üzerinde güç ve kontrol sahibi 
olmaya dayalı duygusal ilişkilerinde kolaylıkla gerçekleşebilir ve bu istismar süreci, “mağdur” tarafindan fark edilemez şekilde manipülatif bir doğada yaşantılanabilir.

\section{Yakın Partner İlişkileri ve Gaslighting}

Yakın partner şiddeti ekseninde yapılan çalışmalar, "gaslighting"in duygusal ilişkilerde oldukça sık yaşantılandığına dair kapsamlı kanıtlar sağlamaktadır (Johnson 2006; Anderson, 2008: 1160; Dutton, Goodman \& Bennett, 1999: 92). Gaslighting, kurbanlar tarafından sistematik olarak deneyimlenen, mağdurdaki kafa karışıklığı ve duygusal çarpıtmalar ile ön planda olan bir duygusal istismar tekniğidir (Sweet, 2019: 855). Ferraro (2006)'ya göre gaslighting, istismarcıların günlük hayatın küçük ayrıntıları dâhil olmak üzere partnerlerinin tüm biyografik özelliklerine kadar her şeye ilişkin algılarını çarpıtarak realitelerini ihlal eden sistematik bir duygusal istismar yöntemidir. Williamson (2010: 1416) ise, "aile içi şiddet" tanımlamasında gaslihting ile ilişkili olarak, istismarcıların kurbanlarının gerçekliklerini yoğun bir şekilde kendi duygusal ihtiyaçları doğrultusunda manipüle etme ve şekillendirme gayretinde oldukları üzerinde durmuştur.

Dobash ve Dobash (1979)'ın gaslighting adına dönüm noktası niteliğinde olan çalışması, istismarcıların partnerlerini sadakatsizliklerine dair gerçek olmayan durumlara bile ikna etme çabasında olduklarını net bir şekilde ortaya koymuştur. Richie (2012)'ye göre, bu manipülasyonlar bireyde kafa karıştırıcı bir etki yaratmaktadır. Yakın partner şiddeti araştırmacıları, kişinin gerçeklik algısını bozmaya ve ruh sağlığını olumsuz yönde etkilemeye yönelik taktikleri henüz operasyonel olarak kavramsallaştıramasalar da bunların bir tür istismar olduğunu açıkça kabul etmektedirler. Bu genel bakış gaslighting'in yaygın olduğunu ancak yakın partner şiddeti araştırmalarında ayrı bir fenomen olarak yeterince teorize edilmediğini göstermektedir. Yakın partner şidderi üzerine yapılan çalışmalar genellikle kişinin gerçeklik algısını bozmaya yönelik yöntemler, zorlayıcı kontroller ve psikolojik istismar konuları zemininde gerçekleştirilmektedir (Stark, 2007). Fiziksel şiddetin yanı sıra aşağılama ve izolasyon gibi duygusal istismar taktikleri de kontrol sağlamak adına sıkça kullanılmaktadır (Anderson, 2008: 1160; Dutton, Goodman \& Bennett, 1999: 92; Giordano ve ark., 2016: 5; Hardesty ve ark., 2015: 836; Johnson, Leone \& Xu, 2014: 190; Kimmel, 2002: 1341; Myhill, 2015: 360; Reed, Miller \& Silverman, 2010: 350; Stark \& Hester, 2019: 90; Tanha ve ark., 2010: 1840). Duygusal istismar, kurbanların aktüel yaşamlarının, benliklerinin ve realitelerinin manipülatif bir zeminde düzenlenmesini içeren kontrol etme çabası olarak değerlendirilmektedir (Hardesty ve ark., 2015: 836; Murphy \& Hoover, 1999: 41; Myhill, 2017: 36; Piipsa, 2002: 880). Yakın partner şiddeti araştırmaları ayrıca psikolojik kontrol taktiklerinin erkekler tarafından kadınlara karşı daha yaygın ve etkili bir şekilde kullanıldığını ve uzun vadede, psikolojik istismarın fiziksel istismara göre ruhsal açıdan daha olumsuz etkileri olduğunu göstermektedir (Anderson, 2009: 1160; Dutton \& Goodman, 2005: 747; Ferraro, 2006; Hester ve ark., 2017: 420; Kelly \& Westmarland, 2016: 116; Murphy \& Hoover 1999: 42; Myhill, 2015: 345; O'Leary, 1999: 12; Strauchler ve ark., 2004: 342; Tanha ve ark, 2010: 1841). Gaslighting belirli oranda, aşağılama ve hakaret gibi psikolojik istismar türleri ile birlikte çalışılmasına rağmen salt olarak sınırlı sayıda araştırmada yer almaktadır. Duygusal istismar teknikleri ve bu tekniklerle ilişkili sosyolojik koşulları ayrıştırmanın gerekli 


\section{Duygusal İstismar ve "Gaslighting" Perspektifinden Kapsaml Bir Değerlendirme}

olduğu konusunda artan bir fikir birliği bulunmaktadır (Myhill, 2015: 346; Stark, 2010). Johnson (2008), gaslighting'e maruz kalan bireyleri ve bu manipülasyonun karakteristiklerini anlayabilmek için daha fazla çalışmaya ihtiyaç olduğunu ifade etmektedir. Bu nedenle, önemli bir duygusal istismar yöntemi olan gaslighting'in mağdur üzerindeki negatif yönelimli sonuçlarını fark etmek gerekmektedir.

Gaslighting'in aile içi şiddetin şaşırtıcı derecede yaygın bir özelliği olduğuna dair kanıt, Ulusal Aile İçi Şiddet Yardım Hattı tarafından 2014 yılında yapılan bir çalışmada belirtilmiştir. Bu çalışmada, aile içi şiddete maruz kalmış, yardım hattını arayan ve ankete katılmayı kabul eden 2500 yetişkin kadına duygusal istismar deneyimleri sorulmuştur (Warshaw ve ark., 2014). "Mevcut veya önceki partnerinizin sizi deliriyor veya aklınızı kaybediyormuş gibi hissettirmek için kasıtlı olarak bir şeyler yaptığını düşünüyor musunuz?" sorusuna mevcut çalışmada \%73.8 evet yanıtı alınmıştır. Ayrıca, örneklemin yaklaşı dörtte üçü gaslighting deneyimi yaşamış ve yarısından fazlası gaslighting'i psikolojik desteğe erişimin önünde bir engel olarak tanımlamıştır. Yine de, bu sonuçlar mevcut çalışma için birtakım veriler sağlamasına rağmen genel olarak yetersiz kalmakta ve duygusal istismar eylemlerini detaylı bir şekilde anlamamıza kısmi oranda yardımcı olmaktadır (Dutton \& Goodman, 2005: 746). Sonuç olarak yakın partner şiddeti, gaslighting'in kontrol içeren ve zorlayıcı ilişkilerin ortak bir özelliği olduğuna dair kanıt sağlamasına rağmen bu yaklaşım spesifik olarak gaslighting'i duygusal istismar stili olarak değerlendirmemiş veya herhangi bir teori çerçevesinde tanımlamamıştır. Gaslighting, iş ve arkadaşlık gibi çeşitli ilişkilerde de deneyimlenebilmesi sebebiyle daha kapsamlı araştırılması gereken bir duygusal istismar yöntemidir (Sweet, 2019: 861).

\section{Narsisist Partnerlerin İstismar Yönelimli Stratejileri ve Amaçları}

Patolojik boyutta narsisistik özelliklere sahip olan istismarcıların taciz eden/sömüren davranışlarının motivasyonlarına ilişkin farklı açıklamalar bulunmaktadır. DSM-5'de (APA, 2013: 333) yer alan narsisistik kişilik bozukluğu (NKB) tanı kriterleri çerçevesinden değerlendirildiğinde istismarcı, sömüren davranışlar aracılığıyla onaylanma arzusunu besleme, benliğini tanımlama ve olumsuz duygular ile başa çıkabilme çabası içerisindedir (Thomaes, Bushman, De Castro \& Stegge, 2009: 1237). Ayrica, narsisistik bireyler başkalarıyla empati kuramama, kişilerarası ilişkilerdeki eksiklikler ve öz saygı ihtiyaçlarını karşılamanın bir yolu olarak "görünürde" yakınlık kurdukları ilişkilerinde sömürücü tutumlar sergileme eğilimindedir. Narsisistik istismarda bulunan bireylerin düşük benlik saygısı yaşamalarının yanısıra her durumda haklı oldukları duygusunu besledikleri de bilinmektedir (Thomaes, Bushman, De Castro \& Stegge, 2009: 1238). Bushman (2018: 234), 30 yıllık bir araştırmanın sonucunda, narsisistik özellikler barındıran şiddet eğilimli bireylerin düşük özgüven yaşadıklarının bir mit olduğunu, başkalarından üstün oldukları algısına sahip olduklarını ve eylemlerinde hak ettikleri saygıyı görmediklerinde öfkelenme olasılıklarının daha yüksek olduklarını önemle belirtmektedir. Narsisistik bireylerin kendileriyle ilgili şişirilmiş benlik görünümü tehdit edildiğinde ve olumsuz bir değerlendirmeye maruz kalındığında, bu durumlarla yüzleşilmemek adına saldırganlıkla tepki verme sürecine girilmesi 'narsisistik yaralanma' olarak ifade edilmektedir (Baumeister, Smart \& Boden, 1996: 18). Bu bireyler duygusal ilişkilerini sonlandırırken, 
narsisistik yaralanmanın ruhsal acısına/sıkıntısına dayanabilmek adına partnerleri tarafından sunulan gerçekleri inkâr etme ve kendilerinden memnun olmadıkları hususları yok sayma -disossiye etme- eğilimindedirler. Ayrıca, bir başkası üzerinde sahip oldukları etki, onlara güç, kontrol ve zevk alma duygusu da yaşatmaktadır (Öztürk, 2021: 11).

Psikanalitik bakış açısına göre narsisistik örüntülerin gelişimi erken çocukluk döneminde kendini göstermektedir. Kernberg (1975), narsisist bireylerin birincil endişelerinin kendi imajları olduğunu ve hayal ettikleri ile gerçek benlik imajları arasında olması gereken ayrımı yapamadıklarını, bunun sonucunda ise gerçek öz benliğine dair muhakemenin gerçekleştirilemediğini vurgulamaktadır. Lowen (1997), ise narsisistik bireylerin düşünce ve davranışlarını, kendi duyguları ekseninde değerlendiremediklerini ifade etmektedir. Duyguları inkâr etmenin şiddeti ve gerçek benliğe yapılan yatırımdan ziyade yaratılan sahte imaja yönelik psikolojik yatırım arttıkça, ilişkiden duyulan rahatsızlığın da artacağı belirtilmiştir. Narsisizm bir spektrum olarak tanımlanırken, yelpazenin en şiddetli ucunda anti-sosyal davranış ve psikopatiyle birlikte ortaya çıkabilen 'habis narsisizm' vardır (Hart \& Hare, 1998: 420; Kernberg, 1998: 379; Ronningstam, 2009: 229). Habis narsisizm, insanları kendi ihtiyaçlarını karşılamak için kullanmak ve bu ihtiyaçları sağlandığında ise karşıdaki bireyin özneliğini ve duygularını hiçe sayarak "kenara atmak" olarak tanımlanmıştır (Malkin, 2015). Habis narsisizm sürecinde, mağdur bireyin gerçekliğini çarpıtmak ve kişilerarası ilişkilerde sorumluluk almamak -hatta tüm sorumluluğu narsisizmini yönelttiği kişiye atfetmek- ile yakından ilişkili duygusal istismar, yoğun bir şekilde yaşantılanmaktadır (Arabi, 2017).

\section{Patolojik Narsisizm ve Duygusal İstismar}

Narsisistik kişilik bozukluğu tanısı alan bireylerin özellikleri hakkında birçok araştırma olmasına rağmen, bu bireyler tarafından istismara uğrayan mağdurların deneyimlerini, narsisistik istismarın özelliklerini ve mağdurlar üzerindeki etkilerini içeren sınırlı sayıda çalışma vardır (Howard, 2019: 648; Maatta \& Ulusiautti, 2018: 1069; Straus, Guonjian, Christian \& Roberts, 2020: 2; Summers \& Summers, 2006: 350). Narsisistik kişilik bozukluğu ekseninde yapılan çalışmalar narsisistik istismara yönelik bilimsel farkındalığı ve bu eksende gerçekleştirilen önleme politikalarını güçlendirmektedir. Özellikle Amerika Birleşik Devletleri'nde istismar mağdurları için kolay erişilebilen zengin içerikli bilgi kaynakları ile psikolojik, sosyolojik ve hukuksal açıdan destek sağlayan sivil toplum örgütleri bulunmaktadır. Duygusal istismar ile mücadele eden birçok mağdur, narsisizm ve duygusal istismara ilişkin bilgiler içeren ve yardımlaşmayı sağlayan Facebook veya Instagram gibi dijital medya platformlarının destek sayfalarını kullanarak çözüm bulabilmektedir. Duygusal istismara ilişkin deneyimlerinde yalnız olduğunu düşünen kişiler, benzer deneyimleri ve istismar kalıplarını anlatan birçok kişi olduğunu görünce bu mağduriyetlerinin olumsuz psikolojik etkileri olabileceğini anlamaya başlayabilmektedir (Howard, 2019: 650).

Mağdurlar, istismar içeren yaşantıları ile ilişkili olarak "kafa karışıklığı" ve "yönlerini kaybetmişlik duygusu" içerisinde olabilirler. Patolojik yaşantılarını fark etmekte güçlük çeken ve öz şüphe içerisinde olan mağdurlar, travmatik yaşantılarını nötralize etmeden bu olumsuz deneyimlerini bir sonraki ilişkilerinde tekrarlama eğiliminde 
olabilmektedirler (Howard, 2019: 651). Louis de Cannonville (2019), "narsisist kurban sendromu"nun, bir terapiste veya sağlık uzmanına başvurmuş olan istismar mağdurlarının temelini oluşturduğu üzerinde durmuştur. Narsisistik kurban sendromu, narsisistik istismarın kurban üzerindeki şiddetli etkilerini kolektif bir biçimde tanımlamak için kullanılan bir kavramdır. Narsisistik kurban sendromunda istismar sonrası mağdurlarda ortaya çıkan negatif duygulara vurgu yapılmaktadır. Narsisistik kurban sendromunun genellikle şok, öfke, korku ve suçluluk gibi temel duyguları barındırdığı ve bu duygular ile birlikte gelişebilen dissosiyatif bozukluklar, travma sonrası stres bozukluğu ve kompleks travma sonrası stres bozukluğu gibi psikopatolojiler ile karakterize olduğu belirtilmiştir. Travma sonrası stres bozukluğu, genellikle tek bir travmatik olaydan sonra, bu duruma bağlı ortaya çıkan yeniden yaşantılama deneyimleri, kaçınma davranışı ve artan uyarılmışlık semptomlarını içermektedir. Kompleks travma sonrası stres bozukluğu ise, uzun süreli ve kronik travmatik yaşantılara maruz kalma sonucu ortaya çıkabilecek işlev kaybı ve olumsuz psikolojik semptomları ifade eder (Resick ve ark., 2012: 244). Travmanın burada ve şimdi yeniden yaşantılanması, travmatik hatıralardan kasıtlı olarak kaçınma ve güncel tehdit hissi bu olumsuz psikolojik semptomlar arasında yer almaktadır (Maercker ve ark., 2013a: 1684; Maercker ve ark., 2013b: 201). Ayrıca kompleks travma sonrası stres bozukluğu ile ilişkilendirilen kronik çocukluk çağı travmalarını deneyimleyenlerin yaşamları boyunca yüksek oranda kişilerarası ilişkilerinde reviktimizasyon riski taşıdıklarını ifade edilmektedir (Duckworth ve Follette, 2011).

Louis de Cannonville (2019), narsisistik istismarla ilişkili travma karakteristiklerinin, "kaçınma davranışı, ilgi kaybı, aktüel hayattan kopukluk hissi, gelecek ile ilgili umutsuzluk, uyku veya yeme bozuklukları, sinirlilik, aşırı uyarılmışlık (hipervijilans), kolayca ürkme, flaşbekler, psikosomatik semptomlar, kendine zarar verme davranışları ve intihar girişimleri” olduğunu belirtmektedir. İstismar yaşantılarıla dolu bir duygusal ilişki içinde; bu ilişkinin seyrini, stres ve zihinsel süreçlerdeki karmaşa deneyimlerinin boyutlarını etkileyen hem mağdur hem de istismar eden kişi için başka önemli süreçler de bulunmaktadır. "Travmatik bağlanma" olarak adlandırılan ve mağdurun onu istismar eden kişi ile olan tutarsız ve sömürücü davranışlarını içeren ilişki deneyiminden özümsediği bağlanma biçimini ifade eden bu kavram, gaslighting ile yakından ilişki göstermektedir. Gaslighter, düşmanca ve saldırgan davranış sergilerken aynı zamanda "görünürde" sevgi ve merhameti içeren hareketlerde de bulunabilir ve bu birbiriyle çelişen deneyim mağdurun istismarcıya olan bağlılığını yeniden canlı hale getirebilir (Dutton \& Painter, 1998: 107).

Travmatik bağlanma, ihanet travma teorisi (betrayal trauma theory) perspektifinden kapsamlı bir şekilde değerlendirilmektedir. Mağdurun güvendiği veya bağlanma paterni geliştirdiği biri tarafından işlenen travma, "ihanet travması" olarak ifade edilmektedir (Freyd, 1996). Mağdurun güvendiği, ona destek ve koruma sağlayan kişi tarafından sömürülmesi yüksek ihanet hissi yaratan bir travmatik deneyim olacağından ötürü şiddetli psikolojik semptomlara yol açabilmektedir. Bağlanma teorisinin temel ilkelerine dayanan ihanet travmasında duygusal ilişki içinde ortaya çıkan olumsuz yaşam olaylarının sıklığı, süresi ve şiddeti, psikiyatrik semptomlara sebep olmaktadır (Bernstein \& Freyd, 2014: 22). Bağlanma kuramı, bireylerin birincil bakımverenleri olan ebeveynleriyle bağların geliştirmek ve süreklilik sağlamak, stres altında veya tehdit edildiğinde bağ kurulan 
figürlerden yakınlık beklemek ideasına dayanmaktadır (Bowlby, 1980). Bireylerin bağlanma stili, gelecekteki ilişkilerinin, kişilik özelliklerinin, ruhsal ve fiziksel sağlı̆̆ının temelini oluşturmaktadır. Hayatta kalma çabası en fazla, istismarcı bir ebeveyne/bakım verene bağımlı olan çocuklar tarafından verilmektedir. İhanet travması, bağlanmanın kurulduğu kişiler tarafindan gerçekleştiğinde, bağlanma hissedilmeyen bireylerden gelen olumsuz tutum ve davranışlara oranla çok daha fazla psikolojik açıdan zarar görmeye sebep olmaktadır (Bernstein \& Freyd, 2014: 23).

İnsanlar ihaneti tespit etme konusunda belirli ölçüde yetenekli olmakla birlikte bu yetenek, hayatta kalmayı tehdit ettiği zaman -özellikle yakın ilişkilerde- sıklıkla fonksiyonunu kaybetmektedir. İhanetin fark edilemediği bu durum "ihanet körlüğü" olarak tanımlanmaktadır. (DePrince, 2005: 130; Gobin \& Freyd, 2009: 250). İstismarın tamamen farkında olmak bağlanma ilişkisini bozabilecek olan "ihanet"in de ortaya çıkarak fark edilmesini sağlar ki bu durum hâlihazırda "güvensiz bağlanma" dinamikleriyle karakterize olan patolojik ilişki dinamiklerinin sonlanmasına neden olur. Bu nedenle, ihanet körlüğü, istismarcıya bağlanma paternini arttıran psikolojik bir tepki olarak görülmektedir (Bernstein \& Freyd, 2014: 251). Dahası, bireyin istismarcı ile ilişkisi ne kadar yakınlık içeriyorsa, ihanet körlüğü potansiyeli de o kadar büyük olur. Mağdurlar hem genellikle istismar edildiklerini fark edememekte hem de bu süreç ile ilgili kendilerini suçlayarak istismarc1larıyla identifiye olabilmektedir (Bernstein \& Freyd, 2014: 27). Dolayısıyla, ihanet körlüğü hem istismarcıyla bağlanmanın olduğu duygusal ilişkiyi sürdürmek hem de bu ilişkiden ayrılmanın mümkün olmadığı durumlarda ruhsal sorunları belirli bir seviyede tutmak için görece işlevseldir ancak bu bağlanma paterninin hâlihazırda patolojik bir dinamiğe sahip olduğu unutulmamalıdır. İhanet körlüğünün istismarciyla bağlanma geliştiren çocuklar için büyük oranda olumsuz psikolojik sonuçları vardır. Bu açıdan bireyler, yeniden mağduriyet (revikimizasyon) ve bazı kümülatif travmalar için yüksek risk altındadır (Maker, Kemmelmeir, \& Peterson 2001: 355). Kronikleşen olumsuz yaşam olayları ile travmatik bağlanma, dissosiyasyon ve reviktimizasyon arasında güçlü ilişkiler bulunmaktadır (Banyard, Williams, \& Siegel, 2002: 25).

Narsisistik istismar, doğrudan tehdide maruz kalmış, izole edilmiş, 'kaçma' firsatı bulmuş olmasına rağmen esir alındıkları kişilere karşı belirli oranda empati ve sempati göstermiş olan mağdurların deneyimlerinde ortaya çıkan "Stockholm Sendromu" ile karşılaştırılmaktadır (Namnyak ve ark., 2008: 7). Hem travmatik bağlanma hem de Stockholm Sendromu "hayatta kalma stratejileri" olarak değerlendirilebilmelerine rağmen istismarcı ile kurulan "görünürde pozitif bağlanmalar", mağdurları ruhsal açıdan önemli boyutlarda negatif yönde etkilemektedir. Bu dinamik, bireylerin neden istismar içeren bir ilişki içinde kaldıkları sorusunu belirli oranda açıklayabilmektedir; çünkü hem travmatik bağlanma hem de Stockholm Sendromu psikolojik anlamda hayatta kalma girişimleri olarak fonksiyon görmektedir. Travmatik bağlanma ve Stockholm Sendromu ile ilişkili olarak mağdurların birbiriyle tutarsız iki ya da daha fazla sayıda biliş ya da bilgi parçalarına sahip olması sonucunda ortaya çıkan ve psikolojik açıdan işlevselliği sekteye uğratan 'bilişsel uyumsuzluk' teorisine de değinmek gerekmektedir (Festinger \& Carlsmith, 1959: 206). Birey, duygusal istismar sonrasında ya bilişsel süreçleri ile çelişen tutumlarını değiştirecek ya da rahatlık ve ruhsal dengeyi yeniden kazanma çabasıyla içinde bulunduğu durumdan kaçınacaktır. İstismar yaşantılarıyla karakterize bir ilişki içerisindeki mağdurlar, 


\section{Patolojik Narsisizm: \\ Duygusal İstismar ve "Gaslighting" Perspektifinden Kapsamlı Bir Değerlendirme}

bazen bu ilişkiye karşı olumsuz tutumlar sergilemekte bazen de, partnerlerinden/eşlerinden ayrılma sürecinde çelişkilerle dolu davranışlarda bulunabilmektedir. İnançları ile çelişki/uyumsuzluk yaratan bir ilişkinin parçası olan mağdur bu uyumsuzluğu azaltmak için, ilişki veya istismara karşı tutumlarını daha olumlu yönde değiştirebilir. $\mathrm{Bu}$ gerçekleşirse, mağdur çok daha tehlikeli bir durumda olabilir, çünkü istismarı aynı düzeyde yaşıyor olmasına rağmen zamanla tutumlarının değişmesine bağlı bilişsel uyumsuzluğun azalması, ilişkide kendini görünürde rahat hissetmesini sağlayabilmektedir (Dare, Guadagno \& Muscanell, 2013: 60). Narsisistik istismar içinde, bilişsel uyumsuzluk, özellikle değersizleştime aşamasında mağdur için belirgin olabilmektedir. Bu aşamada narsisist bireyin ilişkinin başında gösterdiği aşırı özenli, ilgi ve şefkat içeren davranışlarla eşleşmeyen, kontrol ve güç sağlamaya yönelik olumsuz davranışları ortaya çıkmaktadır. Sonuç olarak mağdur, partneri hakkındaki düşüncelerinin ve inançlarının birbiriyle çeliştiği ve zihinsel karmaşa yaşantıladığı bir pozisyonda kalmaktadır (Howard, 2019: 652).

\section{Psikotravmatolojik Açıdan Duygusal İstismar ve Gaslighting}

Dissosiyatif bozukluklar ve travma sonrası stres bozukluğu çalışmalarını tümüyle kapsayan psikotravmatoloji disiplini araştırmalarında özellikle olumsuz yaşam olaylarıyla ilişkili bireylerin tepkilerine, travmaların tedavi ve önleme politikaları ile mağdur deneyimlerine odaklanılmaktadır. Psikotravmatoloji; deprem, yangın, sel gibi doğal afetlerin yanısıra cinsel, duygusal ve fiziksel istismar, göç, sığınmacılık, savaş, terör ve bölgesel çatışmalar gibi insan kaynaklı felaketlerin etkisiyle ortaya çıkan travmatik stres ve travmatik dissosiyasyon gibi psikopatolojik süreçler üzerine hem akademik hem de klinik bağlamdaki çalışmalara katkıda bulunmaktadır (Everly, 1993: 271; Öztürk, 2018a: 31, 2018b: 93; Öztürk, Erdoğan \& Çalıc1, 2019: 213). Öztürk'e göre kronik çocukluk çağı travmalarının kısa ve uzun dönemli sonuçları olan dissosiyatif bozukluklar ile travma sonrası stres bozukluğu birbirleriyle fonksiyon geçişleri olan psikopatolojilerdir. Ayrıca duygusal istismar ve gaslighting'in mağdur üzerindeki negatif yönelimli sonuçlarının travma ile ilişkili psikopatolojilerin gelişebilmesine sebep olacağı da bilinmektedir. Bu doğrultuda spesifik olarak duygusal ilişkilerde istismarın psikotravmatolojik açıdan incelenmesi mağdurda gelişmiş ya da gelişmekte olan psikopatolojiler ile ilgili bilimsel değerlendirilmelerin gerçekleştirilmesine katkı sağlamaktadır. Kültürel yapıyı göz önünde bulunduran psikotravmatolojik yaklaşım, istismar ve istismarın mağdur üzerindeki etkilerini incelerken aynı zamanda kültürel geçmişi kavramaya çalışarak, bireylerin psikoterapi sürecini yargılamadan ve empatik doğada gerçekleştirmektedir (Öztürk, 2020: 30). Travma çalışmaları karşıtı olan akademik kitle ile yoğun ve sistematik bir şekilde mücadele eden ve ulusal/uluslararası bilimsel platformlarda çok sayıda hem teorik hem de klinik çalışmalar yapan Öztürk, erken yaşta başlayan kronik çocukluk çağı travmalarına ve yanlış çocuk yetiştirme stillerine psikotravmatolojik bir perspektiften yaklaşmanın çoğu psikiyatrik hastalıkların temelini anlamada ve tedavide çözüm odaklı yollar geliştirmede katkıda bulunacağı üzerinde durmaktadır (Öztürk \& Derin, 2020: 185). 


\section{SONUÇ}

Kendini aşırı önemseme, başkalarını yok sayma, abartılmış benmerkezcilik ve kişilerarası ilişkilerde problemler ile ilişkilendirilen patolojik narsisizm gösteren bireylerin duygusal ilişkilerinde partnerlerini istismar etmeye eğilimli oldukları bilinmektedir. Narsisistik bireyler, ilişki içerisinde duygusal istismar ve özellikle gaslighting yöntemini uygulayarak partnerleri üzerinden ego temelli ihtiyaçlarını karşılamaktadırlar (Thomaes, Bushman, De Castro \& Stegge, 2009: 1236). Narsisistik birey ile kurulan duygusal ilişkinin belirli aşamaları bulunmaktadır. Duygusal ilişkinin başlangıcında, idealleştirme aşamasında partnerlerini kısa zaman dilimlerinde yoğun bir ilgi ve şefkate boğarlar. İlişkide bağlılık sağlandığında ikinci aşama olan değersizleştirme başlayacak ve terk aşamasında ise gaslighting ile ilişki sonlanacaktır (Howard, 2019: 651). İstismar mağduru tarafından travmatik bir süreç olarak değerlendirilebilen duygusal ilişki sürecinin, psikiyatrik bozukluklara yol açabilecek şiddette olumsuz etkileri olabilmektedir (Öztürk \& Derin, 2020: 185).

Duygusal istismar, kişilik gelişimini negatif yönde etkileyen ve psikiyatrik bozuklukların ortaya çıkmasında tetikleyici olan temel bir faktördür (Herman, 1992; Van der Hart, Nijenhuis \& Steele, 2006). Bununla birlikte, tüm travmatik deneyimlerin kişilik örgütlenmelerine ve diğer psikopatolojilere yol açma olasılığı eşit değildir. Freyd (1996), güvenin optimal bir düzeyde kurulduğu destek ve koruma sağlayan kişi tarafindan sömürülmenin, "ihanet travması" olarak fonksiyon göstermesi sebebiyle şiddetli psikiyatrik semptomlara yol açacağını önemle vurgulamaktadır. Örneğin, bir ebeveyn, bakıcı veya güvenilir bir kişi tarafından işlenen fiziksel, duygusal ve/veya cinsel istismar, mağdurun yakın olmadığı bir kişi tarafından işlenen başka türlü benzer bir istismar türünden daha şiddetli ve olumsuz sonuçlar doğuracaktır. Araştırmalar, ihanet oranının yüksek olduğu travmaların, daha düşük bir ihanet bileşenine sahip olan travmalardan daha fazla travma sonrası stres bozukluğuna, dissosiyatif bozukluklara ve bu olumsuz yaşam olaylarıyla karakterize diğer psikiyatrik hastalıklara sebep olduğunu net bir kesinlikle ortaya çıkarmaktadır (Bernstein ve Freyd, 2014: 25; Kaehler, Babcock, DePrince \& Freyd, 2013: 65; Lawson, Akay-Sullivan, 2020: 681). Ayrıca Öztürk (2020: 8), ruhen üstünden gelinmesi zor olan travmatik yaşantıların kişinin entegratif algılarının sürekliliğini ani ve belirgin düzeyde bozacak yoğunlukta çaresizlik duygusu ve kontrol kaybına sebep olmasının yanısıra korku, bunaltı, depresif duygulanım, benlik saygısında azalma, öfke, suçluluk, utanç, kimlik ve bağlanma sorunlarına temel hazırladığına vurgu yapmaktadır. Bir yandan bireyin kimliğinde entegratif katkılar sağlayan travmatik olmayan yaşantılar ve özdeşimler varken, bunun tam tersi yönünde deneyimlenen olumsuz olaylar ve özdeşimler bireyin kimliğine yabancılaşmasına, dissosiyatif reaksiyonlar göstermesine, istismarcıya bağlanmasına ve o istismarcının amaç ve isteklerini kendisininkilerin yerine koyarak onunla identifikasyon kurmasina sebep olabilmektedir (Öztürk, 2021: 13).

Sonuç olarak, duygusal ilişkilerde gaslighting ve duygusal istismarı "kontrol ve güç" saiki ile kullanan patolojik düzeydeki narsisist bireylerin duygusal istismarı hangi yöntemlerle uyguladığının fark edilmesi, bu istismarla yakından ilişkili olan dissosiyatif bozukluklar ve travma sonrası stres bozukluğu gibi psikopatolojilerin en kısa sürede tedavi edilebilmesi adına temel bir gerekliliktir. Patolojik düzeyde narsisistik özellikler gösteren bireyler duygusal ilişkilerinde sıklıkla partnerine karşı sömürücü tutum ve davranışlarda 
bulunmakta, egonsantrik ihtiyaçlarını onu kontrol ederek ve duygusal açıdan istismar ederek doyurmakta ve kimlik ve benliğe yönelik bir istismar biçimi olarak tanımlanan "gaslighting” yöntemini uygulamaktadır (Campbell \& Foster, 2002: 489; Howard, 2019: 653). Dolayısıyla, patolojik narsisizmin duygusal istismar ve gaslighting perspektifinden kapsamlı bir şekilde değerlendirilmesi, mağdurlarda gelişebilecek olası psikiyatrik tanılarının tespit edilmesine ve onların psikoterapi süreçlerinin travma odaklı bir zeminde yapılandırılmasına katkı sağlamak adına oldukça değerlidir. Yakın ilişki dinamiklerinde patolojik narsisizmin ve gaslightingin psikodissosiyojen bir ajan olarak devreye girmesiyle bireylerde deneyimlenen ihanet travmasının modern psikotravmatoloji paradigmaları yöneliminde daha kısa sürelerde tedavi edilmesini imkanlı kılacağı düşünülmektedir (Öztürk \& Erdoğan, 2021: 1550).

\section{KAYNAKÇA}

Abramson, K.(2014). Turning up the lights on gaslighting. Philos Perspect, 28 (1):130.

Ackerman, R. A., Witt, E. A., Donnellan, M. B., Trzesniewski, K. H., Robins,R. W., \& Kashy, D. A. (2011). What does the narcissistic personality inventory really measure? Assessment, 18(1), 67-87.

Akhtar, S. (1989). Narcissistic personality disorder: Descriptive features and differential diagnosis. Psychiatric Clinics of North America, 12 (3), 505-529.

Akhtar, S. (2003). New Clinical Realms: Pushing the Envelope of Theory and Technique. Lanham, MD: Jason Aronson.

Akhtar, S., \& Thomson, J. A. (1982). Overview: Narcissistic personality disorder. The American Journal of Psychiatry, 139(1), 12-20.

American Psychiatric Association (1987). Diagnostic and statistical manual of mental disorders (3rd ed.). Washington: DC: Author.

American Psychiatric Association (1994). Diagnostic and statistical manual of mental disorders (4th ed.). Washington: DC: Author.

American Psychiatric Association (2000). Diagnostic and statistical manual of mental disorders (4th ed., revision). Washington: DC: Author.

American Psychiatric Association (2013). Diagnostic and statistical manual of mental disorders (5th ed.). Washington: DC: Author.

Anderson, K. L. (2009). Gendering Coercive Control. Violence Against Women, 15(12):1444-57.

Anderson, K.L. (2008). Is Partner Violence Worse in the Context of Control? Journal of Marriage \& Family, 70(5):1157-68.

Arabi, S. (2017). Power: Surviving \& thriving after narcissistic abuse. Brooklyn, NY: Thought Catalog Books. 
Banyard, V. L., Williams, L. M., \& Siegel, J. A. (2002). Retraumatization among adult women sexually abused in childhood: Exploratory analyses in a prospective study. Journal of Child Sexual Abuse: Research, Treatment, \& Program Innovations for Victims, Survivors, \& Offenders, 11(3), 19-48.

Barry, C. T., Frick, P. J., \& Killian, A. L. (2003). The relation of narcissism and selfesteem to conduct problems in children: A preliminary investigation. Journal of Clinical Child and Adolescent Psychology, 32(1), 139-152.

Baumeister, R. F., Smart, L., \& Boden, J. M. (1996). Relation of threatened egotism to violence and aggression: The dark side of high selfesteem. Psychological Review, 103(1), 5-33.

Bernstein, R. E., \& Freyd, J. J. (2014). Trauma at home: How betrayal trauma and attachment theories understand the human response to abuse by an attachment figure. Attachment: New Directions in Psychotherapy and Relational Psychoanalysis, 8, 18-41.

Bies, R. J. (2009). Sounds of Silence: Identifying New Motives and Behaviors, Greenberg ve Edwards (Editör), Voice and Silence in Organizations, (157-172), United Kingdom: Emerald Group Publishing.

Bonchay, B. (2018). Narcissistic abuse affects over 158 million people in the U.S. Retrieved from Psychcentral: https://psychcentral.com/lib/narcissistic-abuse-affects-over158-million-people-in-the-u-s/.

Bowlby, J. (1980). Attachment and Loss. Vol. 3, Loss. Basic Books.

Bowlby, J. (1973). Attachment and loss, vol. II: Separation. New York, NY:Basic Books.

Brown, J. (2017). Millennials are the most narcissistic generation ever. Retrieved from https://www.indy100.com/article/millennialnarcissistic-gen-y-narcissism-scalestudy-7588141.

Bushman, B. (2018). Narcissism, fame seeking and mass shootings. American Behavioural Scientist, 62(2), 229-241.

Bushman, B. J., \& Baumeister, R. F. (1998). Threatened egotism, narcissism, selfesteem, and direct and displaced aggression: Does self-love or self-hate lead to violence? Journal of Personality and Social Psychology, 75(1), 219-229.

Calef, V. \& Weinshel, E.M (1981). Some clinical consequences of introjection: gaslighting. Psychoanal Q, 50(1):44-66.

Campbell, W. K., Reeder, G. D., Sedikides, C., \& Elliot, A. J. (2000). Narcissism and comparative self-enhancement strategies. Journal of Research in Personality, 34(3), 329-347.

Campbell, W. K. \& Foster, C. A. (2002). Narcissism and commitment in romantic relationships: An investment model analysis. Personality and Social Psychology Bulletin, 28(4), 484-495.

Carpenter, A. (2018). Gaslighting America. Harper Collins, New York. 
Duygusal İstismar ve "Gaslighting" Perspektifinden Kapsamlı Bir Değerlendirme

Dare, B., Guadagno, R., \& Muscanell, N. (2013). Commitment: The key to women staying in abusive relationships. Journal of Interpersonal Relations, Intergroup Relations and Identity, 6, 58-64.

Demause, 1.(1979). Historical group-fantasies. The journal of Psychohistory. 7(1):170.

DePrince, A. P. (2005). Social cognition and revictimization risk. Journal of Trauma \& Dissociation, 6(1), 125-141.

Dickinson, K. \& Pincus, A. (2003). Interpersonal analysis of grandiose and vulnerable narcissism. Journal of Personality Disorders, 17(3), 188-207.

Dobash, R. E., \& Dobash R. (1979). Violence Against Wives: A Case Against the Patriarchy. New York: Free Press.

Dökmen,Ü.(1997). Illetişim Çatışmaları Ve Empati. Sistem Yayıncılık,14. Baskı.

Duckworth, M. P., \& Follette, V. M. (Eds.). (2011). Retraumatization: Assessment, treatment, and prevention. London, England: Routledge.

Dutton, M. A., \& Goodman, L.A. (2005). Coercion in Intimate Partner Violence: Toward a New Conceptualization. Sex Roles, 52(11-12):743-56.

Dutton, M. A., Goodman, L.A., Bennett, L. (1999). Court-Involved Battered Women's Responses to Violence: The Role of Psychological, Physical, and Sexual Abuse. Violence and Victims, 14(1):89-104.

Dutton, D.G \& Painter, S. (1993). Emotional attachments in abusive relationships: a test of traumatic bonding theory. Violence and victims, 8(2):105-119.

Eldoğan, N. (2016). Hangi Narsizm? Büyüklenmeci ve Kırılgan Narsizmin Karşılaştırılmasına İlişkin Bir Gözden Geçirme, Türk Psikoloji Yazıları, 19 (37), 1-10.

Erickson, E. H. (1968). Identity, youth, crisis. New York: WW Norton.

Everly, G.S. (1993). Psychotraumatology: A two-factor formulation of posttraumatic stress. Integrative Physiological and Behavioral Science, 28(3), 270-278.

Ferenczi (1984). Confusion. In J. Masson (Ed.), Freud: The assault on truth (pp. 293-294). London, UK: Ballantine Books.

Ferraro, K. J. (2006). Neither Angels nor Demons: Women, Crime, and Victimization. Boston: Northeastern University Press.

Festinger, L., \& Carlsmith, J. (1959). Cognitive consequences of forced compliance. Journal of Abnormal and Social Psychology, 58(2), 203-210.

Freud, S. (1957). On narcissism: An introduction. In J. Strachey (Ed. and Trans.), The standard edition of the complete works of Sigmund Freud (Vol. 14, pp. 117140). London: Hogarth Press.

Freyd, J. J. (1996). Betrayal trauma: The logic of forgetting childhood abuse. Harvard University Press. 
Gabbard, G. O. (1989). Two subtypes of narcissistic personality disorder. Bulletin of the Menninger Clinic, 53(6), 527-532.

Gabbard, G. O. (1998). Transference and countertransference in the treatment of narcissistic patients. E. Ronningstam (Ed.), Disorders of narcissism: Diagnostic, clinical, and empirical implications içinde (125-145). Washington DC: American Psychiatric Press.

Giordano, P. C., Copp, J.E., Longmore, M.A., \& Manning. W. D. (2016). Anger, Control, and Intimate Partner Violence in Young Adulthood. Journal of Family Violence, 31(1):1-13.

Gobin, R. L., \& Freyd, J. J. (2009). Betrayal and revictimization: Preliminary findings. Psychological Trauma: Theory, Research, Practice, and Policy, 1(3), 242-257.

Hardesty, J. L., Crossman, K.A., Haselschwerdt, M.L., Raffaelli, M., Ogolsky, B.G., \& Johnson. M. P. (2015). Toward a Standard Approach to Operationalizing Coercive Control and Classifying Violence Types. Journal of Marriage and Family, 77(4):833-43.

Hart, S., \& Hare, R. (1998). The association between psychopathy and narcissism: Theoretical views and empirical evidence. In E. Ronningstam (Ed.), Disorders of narcissism: Diagnostic, clinical and empirical implications (pp. 415-436). Washington, DC: American Psychiatric Publishing.

Herman, J. (2015). Trauma and recovery: The aftermath of violence - from domestic abuse to political terror. Philadelphia, PA: Basic Books.

Hester, M., Jones,C., Williamson, E. , Fahmy, E., \& Feder, G. (2017). Is It Coercive Controlling Violence? A Cross-Sectional Domestic Violence and Abuse Survey of Men Attending General Practice in England. Psychology of Violence, 7(3):417-27.

Howard, V. (2019). Recognising Narcissistic Abuse and the Implications for Mental Health Nursing Practice, Issues in Mental Health Nursing, 40(8), 644-654.

Jang, K. L., Livesley, W. J, Vernon, P. A. ve Jackson, D. N. (1996). Heritability of personality disorder traits: A twin study. Acta Psychiatrica Scandinavica, 94, 438-444.

Johnson, M. P., Leone, J. M., \& Xu, Y. (2014). Intimate Terrorism and Situational Couple Violence in General Surveys: Ex-Spouses Required. Violence Against Women, 20(2):186-207.

Johnson, M.P. (2006). "Conflict and Control: Gender Symmetry and Asymmetry in Domestic Violence”. Violence Against Women, 12(11),1003-18.

Johnson, M.P. (2008). A Typology of Domestic Violence: Intimate Terrorism, Violent Resistance, and Situational Couple Violence. Boston: Northeastern University Press.

Kaehler, L. A., Babcock, R., DePrince, A. P., \& Freyd, J. J. (2013). Betrayal trauma. In J. D. Ford \& C. A. Courtois (Eds.), Treating complex traumatic stress disorders in children and adolescents: Scientific foundations and therapeutic models (p. 62-78). The Guilford Press. 
Duygusal İstismar ve "Gaslighting" Perspektifinden Kapsaml Bir Değerlendirme

Karpel, M. (1976). Individuation: From fusion to dialogue. Family Process, 15(1), 65-82.

Kashima, Y., Foddy, M. \& Platow, M. (2002). Self and identity: Personal, social, and symbolic. Psychology press (pp. 103-123).

Kealy, D., \& Rasmussen, B. (2012). Veiled and vulnerable: The other side of grandiose narcissism. Clinical Social Work Journal, 40(3), 356-365.

Kelly, L., \& Westmarland. N. (2016). Naming and Defining 'Domestic Violence': Lessons from Research with Violent Men. Feminist Review, 112(1), 113-27.

Kernberg, O. F. (1975). Borderline conditions and pathological narcissism. Northvale, NJ: Jason Aronson.

Kernberg, O. F. (2010). Narcissistic personality disorder. In J. F. Clarkin, P.Fonagy, \& G. O. Gabbard (Eds.), Psychodynamic therapy for personality disorders. A clinical handbook (pp. 257-287). Arlington, TX: American Psychiatric.

Kernberg, O. (1998). The psychotherapeutic management of psychopathic, narcissistic and paranoid transference. In T. Millon, E. Simonsen, M. Birkit-Smith, \& R. D. Davis (Eds.), Psychopathy, antisocial, violent and criminal behavior (pp. 372-392). New York, NY: Guildford Press.

Kimmel, M. S. (2002). Gender Symmetry' in Domestic Violence: A Substantive and Methodological Research Review. Violence Against Women, 8(11):1332-63.

Kohut, H. (1977). The restoration of the self. New York, NY: International Universities Press.

Kohut, H. (1972). Thoughts on narcissism and narcissistic rage. The Psychoanalytic Study of the Child, 27(1), 360-400.

Lapsley, D. K., \& Stey, P. (2010). Separation-individuation. Corsini Encyclopedia of Psychology, 4.

Lawson, M.D., \& Akay-Sullivan, S. (2020) Considerations of Dissociation, Betrayal Trauma, and Complex Trauma in the Treatment of Incest, Journal of Child Sexual Abuse, 29(6), 677-696.

Louis de Cannonville, C. (2018). Understanding cognitive dissonance, trauma bonding and infantile regression. Retrieved from https://narcissisticbehavior.net/.

Lowen, A. (1997). Narcissism: Denial of the true self. New York, NY: Touchstone.

Maatta, M., Ulusiautti, S. (2020). 'My life felt like a cage without an exit' narratives of childhood under the abuse of a narcissistic mother. Early child development care, 190(7), 1065-1079.

Maercker, A., Brewin, C. R., Bryant, R. A., Cloitre, M., Reed, G. M., Van Ommeren, M., Humayun, A, Jones, L.M., Kagee, A., Llosa, A.E., Rousseau, C., Somasundaram, D.J., Souza, R., Suzuki, Y., Weissbecker, I., Wessely, S.C., First, M.B., \& Saxena, S. (2013a). Proposals for mental disorders specifically associated with stress in the international classification of diseases-11. The Lancet, 381(9878), 1683-1685. 
Maercker, A., Brewin, C. R., Bryant, R. A., Cloitre, M., Van Ommeren, M., Jones, L., Humayan, A., Kagee, A., LLosa, A.E., Rousseau, C., Somasundaram, D.J., Souza, R., Yuriko, S., Weissbecker, I., Wessely, S.C., First, M.B., \& Reed, G. M. (2013b). Diagnosis and classification of disorders specifically associated with stress: Proposals for ICD-11. World Psychiatry, 12(3), 198-206.

Mahler, M., Pine, F., \& Bergman, A. (1975). The psychological birth of the human infant. New York, NY: Basic Books.

Maker, A. H., Kemmelmeir, M., \& Peterson, C. (2001). Child sexual abuse, peer sexual abuse, and sexual assault in adulthood: A multi-risk model of revictimization. Journal of Traumatic Stress, 14(2), 351-368.

Malkin, C. (2015). Rethinking narcissism: The secret to recognizing and coping with narcissists. New York, NY: Harper Perennial.

Masterson, J. F. (1993). The emerging self: A developmental self and object relations approach to the treatment of the closet narcissistic disorder of the self. Brunner/Mazel, New York.

Millon, T. (1981). Disorders of personality: DSM-Ill: Axis 11. New York: Wiley.

Miller, J. D., \& Campbell, W. K. (2008). Comparing clinical and social-personality conceptualizations of narcissism. Journal of Personality,76 (3), 449-476.

Miller, A. (1995). The drama of being a child: The search for the true self. London, UK: Virago.

Miller, J. D., Widiger, T. A., \& Campbell, W. K. (2010). Narcissistic personality disorder and the DSM-V. Journal of Abnormal Psychology, 119 (4), 640-649.

Miller, J. D., Gentile, B., Wilson, L., \& Campbell, W. K. (2013). Grandiose and vulnerable narcissism and the DSM-5 pathological personality trait model. Journal of Personality Assessment, 95 (3), 284-290.

Morf, C. C., \& Rhodewalt, F. (2001). Unraveling the paradoxes of narcissism: A dynamic self-regulatory processing model. Psychological Inquiry, 12(4), 177-196.

Murphy, C.M., \& Hoover. S. A. (1999). Measuring Emotional Abuse in Dating Relationships as a Multifactorial Construct. Violence and Victims, 14(1):39-53.

Myhill, A. (2015). Measuring Coercive Control: What Can We Learn from National Population Surveys? Violence Against Women, 21(3):355-75.

Myhill, A. (2017). Measuring Domestic Violence: Context Is Everything. Journal of Gender-Based Violence, 1(1):33-44.

Namnyak, M., Tufton, N., Szekely, R., Toal, M., Worboys, S., \& Sampson, E. (2008). Stockholm syndrome: Psychiatric diagnosis or urban myth. Acta Psychiatrica Scandinavica, 117, 4-11.

O’Leary, K. D. (1999). Psychological Abuse: A Variable Deserving Critical Attention in Domestic Violence. Violence and Victims, 14(1):3-23. 
Otway, L. J. \& Vignoles, V. L. (2006). Narcissism and childhood recollections: A quantitative test of psychoanalytic predictions. Personality and Social Psychology Bulletin, $32,104-116$.

Özsaydın, S. (1984). Psikiyatri. Sanal Matbaacıl1k, cilt:7, İstanbul.

Öztürk, E. (2018a). Travma merkezli alyans model terapi: dissosiyatif kimlik bozukluğunun psikoterapisi. E. Öztürk, (Ed.), Ruhsal travma ve dissosiyasyon içinde (3138). Ankara: Türkiye Klinikleri.

Öztürk, E. (2018b). Psikotarih ruhsal travma ve dissosiyasyon, O. Celbiş, (Ed.). Turaz Akademi 2018 içinde (1. Baskı) (92-106). Ankara: Akademisyen Kitabevi.

Öztürk, E., Erdoğan, B., \& Çalıcı, C. (2019). Göçmenler ve ruh sağlığı göçmenler ve göç süreci: psikotravmatolojik bir değerlendirme. H. Sakız, \& H. Apak, (Ed.). Türkiye'de Göçmen Kapsayıcılı̆̆l: sorundan firsata dönüşüm önerileri içinde (213-226). Ankara: Pegem Akademi.

Öztürk, E. (2020). Travma ve Dissosiyasyon: Psikotravmatoloji Temel Kitabı. 2. Baskı. İstanbul: Nobel Tıp Kitabevi.

Öztürk, E., Derin, G. (2020). Psikotravmatoloji. Aydın insan ve toplum dergisi, 6(2), 181-214.

Öztürk E. (2021). Disfonksiyonel aile modellerinden fonksiyonel aile modeline:"Doğal ve rehber ebeveynlik stili". Öztürk E, editör. Aile Psikopatolojisi. 1. Bask1. Ankara: Türkiye Klinikleri; p.1-39.

Öztürk, E., \& Erdoğan, B. (2021). Betrayal trauma, dissociative experiences and dysfunctional family dynamics: Flashbacks, self-harming behaviors and suicide attempts in post-traumatic stress disorder and dissociative disorders. Medicine-Science, 10(4), 15506.

Piipsa, M. (2002). Complexity of Patterns of Violence Against Women in Heterosexual Partnerships. Violence Against Women, 18(7):873-900.

Pincus, A. L., \& Lukowitsky, M. R. (2010). Pathological narcissism and narcissistic personality disorder. Annual Review of Clinical Psychology, 6, 421-446.

Pincus, A. L., \& Roche, M. J. (2011). Narcissistic grandiosity and narcissistic vulnerability. W. K. Campbell \& J. D. Miller (Eds.), The handbook of narcissism and narcissistic personality disorder: Theoretical approaches, empirical findings, and treatments içinde (31-40). Hoboken, NJ, US: John Wiley \& Sons Inc.

Rappoport, A. (2005). Co-narcissism: How we accommodate to narcissistic parents. The Therapist, 1, 1-8.

Reed, E., Miller, A.E. \& Silverman, J.G. (2010). Losing the 'Gender' in GenderBased Violence: The Missteps of Research on Dating and Intimate Partner Violence. Violence Against Women, 16(3):348-54.

Resick, P. A., Bovin, M. J., Calloway, A. L., Dick, A. M., King, M. W., Mitchell, K. S., Suvak, M.K., Wells, S.Y., Stirman, S.W., \& Wolf, E. J. (2012). A critical evaluation of 
the complex PTSD literature: Implications for DSM-V. Journal of Traumatic Stress, 25(3), 241-251.

Richie, B. E. (2012). Arrested Justice: Black Women, Violence, and America's Prison Nation. New York: New York University Press.

Ritter, K., Dziobek, I., Preisler, S., Ruter, A., Vater, A., Fydrich, T., Claas-Hinrich, L., Heekeren, H.R., \& Roepke, S. (2011). Lack of empathy in patients with narcissistic personality disorder. Psychiatry Research, 187(1-2), 241-247.

Ronningstam, E., \& Gunderson, J. (1991). Differentiating borderline personality disorder from narcissistic personality disorder. Journal of Personality Disorder, 5(3), 225232.

Ronningstam, E. (2009). Narcissistic personality disorder: Facing DSM-V. Psychiatric Annals, 39(3), 111-121.

Rose, P. (2001). The happy and unhappy faces of narcissism. Personality and Individual Differences, 33(3), 379-391.

Rozenblatt, S. (2002). In Defence of Self: The relationship of Self- Esteem and Narcissim to Aggressive Behavior. Long Island University, Psychology, Yayınlanmış Doktora Tezi, USA.

Sedikides, C., Campbell, W. K., Reeder, G. D., Elliot, A. J., \& Gregg, A. P. (2002). Do others bring out the worst in narcissists? The "others exist for me" illusion. In Y. Kashima, M. Foddy, \& M. J. Platow (Eds.), Self and identity: Personal, social, and symbolic (p. 103-124).

Sedikides, C., Campbell, W. K., Reeder, G., Elliot, A. J., \& Gregg, A. P.(2002). Do others bring out the worst in narcissists? The "others exist for me" illusion. In Y. Kashima, M. Foddy, \& M. Platow (Eds.), Self and identity: Personal, Social, and symbolic (pp. 103-123).

Simon, G. (2010), In sheep's clothing: Understanding and dealing with manipulative people. Little Rock, AR: Parkhurst Brothers, Inc.

Smith, M.E. (2007). Self-deception among men who are mandated to attend a batterer intervention program. Perspect Psychiatr Care, 43(4):193-203.

Spear, A.D. (2020).Gaslighting, Confabulation, and Epistemic Innocence. Topoi, 39, 229-241.

Spencer, T. (2001). Should We Call Them Human? Narcissistic Personality Disorder And Co-Morbid Diagnoses. Gale Encyclopedia Of Psychology. 2nd Ed. In Association With The Gale Group And Looksmart.

Stark, E., \& Hester, M. (2019). Coercive Control: Update and Review. Violence Against Women, 25(1):81-104.

Stark, E. (2010). Do Violent Acts Equal Abuse? Resolving the Gender Parity/Asymmetry Dilemma. Sex Roles, 62(3-4):201-11. 
Stark, E. (2007). Coercive Control: How Men Entrap Women in Personal Life. New York: Oxford University Press.

Stark, C.A. (2019). Gaslighting, misogyny, and psycho- logical oppression. The monist, 102(2): 221-35.

Stern, R. (2007). The gaslight effect. Random House, New York.

Stern, R. (2018). The Gaslight Effect: How to Spot and Survive the Hidden Manipulation Others Use to Control Your Life. New York: Harmony Books.

Strauchler, O., McCloskey, K., Malloy, K., Sitaker, M., Grigsby, N. \& Gillig, P. (2004). Humiliation, Manipulation, and Control: Evidence of Centrality in Domestic Violence against an Adult Partner. Journal of Family Violence, 19(6):339-54.

Strause, H.E., Guonjian, E.H., Christian, E. \& Roberts, R.R. (2020). Assessment of intimate partner violence abuse ratings by recently abused and never abused women. $B M C$ women's health, 20(181); 1-5.

Sweet, P.L. (2019). The sociology of gaslighting. American Sociological Review, 84(5), 851-875.

Summers, D.M. \& Summers, C.C. (2006). Unadulterated arrogance: autopsy of the narcissistic parental alienator. The american journal of family therapy, 34; 339-428.

Talu, N.(2010). Modernlik söylemi: endişeli bakışlarda modern birey. METU JFA, 27(2), 141-171.

Tanha, M., Beck, C. J. A., Figueredo, A. J., \& Raghavan, C. (2010). Sex Differences in Intimate Partner Violence and the Use of Coercive Control as a Motivational Factor for Intimate Partner Violence. Journal of Interpersonal Violence, 25(10):1836-54.

Thomaes, S., Bushman, B., De Castro, B., \& Stegge, H. (2009). What makes narcissists bloom? A framework for research on the etiology and development of narcissism. Development and Psychopathology, 21(04), 1233-1247.

Trumpeter, N. N., Watson, P. J., O'Leary, B. J., \& Weathington, B. L. (2008). Selffunctioning and perceived parenting: Relations of parental empathy and love inconsistency with narcissism, depression, and self-esteem. The Journal of Genetic Psychology, 169(1), 51-71.

Türktan, Ş \& Savran, C. (2010). Çocuklarda ve Ergenlerde Ebeveyne Bağlanma, Özgüven ve Okul Başarısı İlişkisi, İçinde: Solmuş T, Bağlanma, Evlilik ve Aile Psikolojisi, İstanbul: Sistem Yayınc1l1k, 243-258.

Twenge, J. M., Konrath, S., Foster, J. D., Keith Campbell, W., \& Bushman,B. J. (2008). Egos inflating over time: A cross-temporal meta-analysis of the narcissistic personality inventory. Journal of Personality, 76(4), 875-902.

Twenge, J.M., Konrath, S., Foster, J.D., Campbell, W.K., \& Bushman, B.J. (2008). Further evidence of an increase in narcissism among college students. Journal of Personality, 76(4): 919-928. 
Wagers, S.M. (2015). Deconstructing the 'power and control motive': Moving beyond a unidimensional view of power in domestic violence. Partner Abuse, 6(2), 230242.

Wardetzki, Barbel (2019). Dişi narsisizm: uçlarda yaşayanlar ve kabul görmeye olan açlık. Dorlion yayınları. Ankara. 1. bask1. s9-25.

Warshaw, C., Lyon, E., Bland, P. J., Phillips, H., \& Hooper.M. (2014). Mental Health and Substance Use Coercion Surveys: Report from the National Center on Domestic Violence, Trauma, \& Mental Health and the National Domestic Violence Hotline.

(http://www.nationalcenterdvtraumamh.org/wpcontent/uploads/2014/10/NCDVTMH_N DVH_MHSUCoercionSurveyReport_2014-2.pdf).

Welch, B., (2008). State of confusion: political manipulation and the assault on the American mind. St. Martin's Press. New York, NY.

Williamson, E. (2010). Living in the World of the Domestic Violence Perpetrator: Negotiating the Unreality of Coercive Control. Violence Against Women, 16(12):1412-23.

Wink, P. (1991). Two faces of narcissism. Journal of Personality and Social Psychology, 61(4), 590-597.

White, D., Szabo, M., \& Tiliopoulos, N. (2018). Exploring the relationship between narcissism and extreme altruism. The American Journal of Psychology, 131(1), 65-80.

Vaknin, S. (2019). Narcissists, narcissistic supply and sources of supply. Retrieved from http://samvak.tripod.com/faq76.html\#narcissisticsupply.

Van der Hart, O., Nijenhuis, E. R. S., \& Steele, K. (2006). The haunted self: Structural dissociation and the treatment of chronic traumatization. W W Norton \& Co.

Vickie Howard (2019). Recognising Narcissistic Abuse and the Implications for Mental Health Nursing Practice, Issues in Mental Health Nursing, 40(8), 644-654.

Yalçın, M.A., Öztürk, E. (2018). Cinsel saldırı suçu mağduru kadınlara karşı toplumsal tutumlar ile adil dünya inancı ve çelişik duygulu cinsiyetçiliğin ilişkisi. Türkiye Klinikleri Adli Tip Dergisi, 5(2):43-51. 